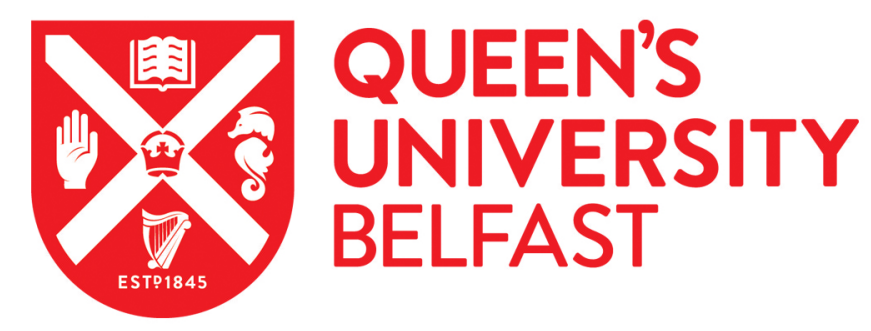

\title{
LCST-phase behavior and complexation with water of an ionic liquid incorporating the 5-phenyltetrazolate anion
}

Moura, L., Brown, L. C., Blesic, M., \& Holbrey, J. D. (2017). LCST-phase behavior and complexation with water of an ionic liquid incorporating the 5-phenyltetrazolate anion. ChemPhysChem, 18(23), 3384-3389.

https://doi.org/10.1002/cphc.201700942

Published in:

ChemPhysChem

Document Version:

Peer reviewed version

Queen's University Belfast - Research Portal:

Link to publication record in Queen's University Belfast Research Portal

Publisher rights

Copyright 2017 Wiley. This work is made available online in accordance with the publisher's policies. Please refer to any applicable terms of use of the publisher.

\section{General rights}

Copyright for the publications made accessible via the Queen's University Belfast Research Portal is retained by the author(s) and / or other copyright owners and it is a condition of accessing these publications that users recognise and abide by the legal requirements associated with these rights.

Take down policy

The Research Portal is Queen's institutional repository that provides access to Queen's research output. Every effort has been made to ensure that content in the Research Portal does not infringe any person's rights, or applicable UK laws. If you discover content in the Research Portal that you believe breaches copyright or violates any law, please contact openaccess@qub.ac.uk. 


\title{
LCST-phase behavior and complexation with water of an ionic liquid incorporating the 5-phenyltetrazolate anion
}

Leila Moura, ${ }^{[a]}$ Lucy C. Brown, ${ }^{[a]}$ Marijana Blesic ${ }^{[a]}$ and John D. Holbrey ${ }^{*}[a]$

\author{
School of Chemistry and Chemical Engineering \\ Queen's University Belfast \\ Belfast BT9 5AG, United Kingdom \\ E-mail: j.holbrey@qub.ac.uk
}

\begin{abstract}
The use of 5-phenyltetrazole, a bioisostere of benzoic acid, as an anion source to prepare an ionic liquid is described for the first time. Tetrabutylphosphonium 5-phenyltetrazolate undergoes phase separation from water with lower critical solution temperature phase behavior, in contrast to completely water miscible tetrabutylphosphonium benzoate, and also exhibits strong complexation with water with both eutectic and peritectic behavior that has not previously been observed in ionic liquid + water systems. The anhydrous and trihydrate salts were isolated and characterized by single crystal Xray diffraction.
\end{abstract}

\section{Introduction}

Since the first recognition that VOCs could be substituted by hydrophobic ionic liquids (ILs) in aqueous liquid-liquid separation schemes,,$^{[1]}$ there have been numerous efforts to exploit them in separation and extraction processes. ${ }^{[2]}$ In general, perfluorinated anions are used as the method of choice to induce hydrophobicity, ${ }^{[3]}$ with a shift in focus from the use of hexafluorophosphate anions due to their

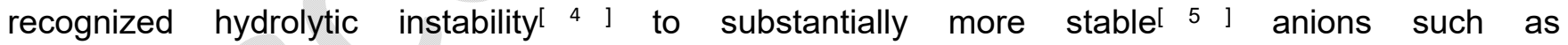
bis(\{trifluoromethyl\}sulfonyl)imide ${ }^{[6]}$ and tris(perfluoroalkyl)-trifluorophosphate. ${ }^{[7]}$

Hydrophilic ionic liquids also be induced to form aqueous biphasic systems with water by 'salting out' from water ${ }^{8]}$ using kosmotropic salts ${ }^{[9]}$ and/or temperature changes. ${ }^{[10]}$ Interestingly, the cation/anion pair that is 'forced' out from the bulk aqueous phase corresponds to the most hydrophobic combination of ions. Substitution of one ion by a correspondingly more hydrophobic one enables more facile phase separation and in extremis, can lead to spontaneous phase separation of hydrophobic ionic liquids from water without application of additional stimuli such as addition of salts or pressure. As such, understanding and controlling the interactions between water molecules and IL anions seems key to gaining insight into these critical phenomena. 
Ohno and co-workers ${ }^{[11,12]}$ have examined a variety of IL/water systems containing the intermediate to moderately hydrophobic tetrabutylphosphonium $\left(\left[\mathrm{P}_{4444}\right]^{+}\right)$cation with a range of nonfluorinated anions. Along the pathway from complete miscibility with water through to spontaneous biphase formation when the ILs contained sufficiently hydrophobic ions, they suggested that the observation of lower critical solubility temperature (LCST) phase behavior could only occur in systems above a limiting solubility threshold of seven water molecules per ion pair in the $\mathrm{IL}$ at $60{ }^{\circ} \mathrm{C}$. Thus, consideration of the extent of ion hydration is crucial to understanding how to generate either LCST mixtures or intrinsically hydrophobic ILs.

Comparing tetrabutylphosphonium benzoate and salicylate $\left(\left[\mathrm{P}_{4444}\right][\mathrm{Bz}]\right.$ and $\left[\mathrm{P}_{4444}\right][\mathrm{Sal}]$ in Figure 1), ${ }^{13]}$ LCST behavior with water was reported for $\left[P_{4444}\right][S a l]$ whereas $\left[P_{4444}\right][B z]$ was completely miscible. This appears, at first, to be counter intuitive since the [Sal] ${ }^{-}$anion has an additional hydroxyl group compared to [Bz]- This was rationalized in terms of intramolecular hydrogen bonding between the salicylate $-\mathrm{OH}$ and $-\mathrm{COO}^{-}$groups reducing the availability of sites for intermolecular hydrogenbonding to water.

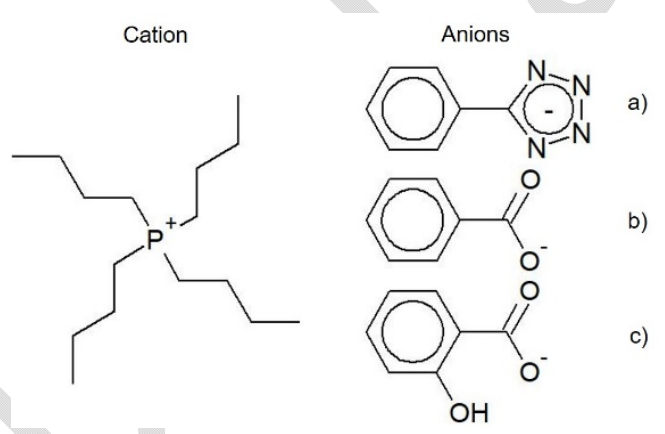

Figure 1. Structure of the cation tetrabutylphosphonium, $\left[\mathrm{P}_{4444}\right]^{+}$and the anions (a) 5-phenyltetrazolate ([Ph-tet] $\left.]^{-}\right),(\mathrm{b})$ benzoate $\left([\mathrm{Bz}]^{-}\right)$, and (c) salicylate ([Sal] $\left.]^{-}\right)$.

Applying 5-substituted-tetrazoles as (bio)isosteres of carboxylic acids is a widely used synthetic strategy in medicinal chemistry. ${ }^{[14]}$ The pKa values of tetrazoles are similar to those of the corresponding carboxylic acids. Ab initio calculations ${ }^{[15]}$ suggest that water-tetrazolate hydrogen-bonds are about $15-18 \mathrm{~kJ} \mathrm{~mol}^{-1}$ weaker than those between corresponding carboxylate anions and water.

We reasoned that ILs prepared with 5-substituted tetrazolate anions, as isosteric analogues of substituted carboxylates, should exhibit greater hydrophobicity and hence immiscibility with bulk water as a result of the general reduction in strength of individual hydrogen bonds to water and the increased charge delocalization anticipated in tetrazolate ring compared to a carboxylate function. To test this we examined the solid-liquid equilibrium (SLE) and liquid-liquid equilibrium (LLE) phase behavior of tetrabutylphosphonium 5-phenyltetrazolate ( $\left[\mathrm{P}_{4444}\right][\mathrm{Ph}$-tet $]$, Figure 1) with water which provides valuable 
insights into the molecular level interactions between the IL and water including the formation of anhydrous and hydrated crystalline solids. Additionally, a comparison is made of the phase behavior of the $\left[\mathrm{P}_{4444}\right][\mathrm{Ph}$-tet $] /$ water system to that of the corresponding $\left[\mathrm{P}_{4444}\right][\mathrm{Bz}]$ and $\left[\mathrm{P}_{4444}\right][\mathrm{Sal}] \mathrm{ILs} .^{[13]}$

\section{Results and Discussion}

$\left[\mathrm{P}_{4444}\right]\left[\mathrm{Ph}\right.$-tet] was prepared by neutralization of aqueous $\left[\mathrm{P}_{4444}\right] \mathrm{OH}$ with a solution of 5-phenyl-tetrazole in water, followed by extraction with ethyl acetate, drying and removal of the solvent as a colorless fluid that crystallized slowly on standing $\left(\mathrm{mp} 74{ }^{\circ} \mathrm{C}\right) . \ddagger$ The presence of deprotonated 5-phenyl-tetrazolate anions was confirmed by NMR and IR spectroscopy and single crystal XRD. In the ${ }^{1} \mathrm{H}$ NMR spectrum, the broad signal from the acidic tetrazole $\mathrm{N}-\mathrm{H}$ hydrogen at $16.78 \mathrm{ppm}$ is absent in the IL. Similarly, IR vibrational bands associated with $\mathrm{N}-\mathrm{H}$ stretches and vibrations in 5-phenyl-tetrazole are also absent from the IR spectrum of the ionic liquid (see Supplemental Information).

Crystals of $\left[\mathrm{P}_{4444}\right][\mathrm{Ph}$-tet] were obtained by slow cooling of the neat ionic liquid to just below the melting point. The single crystal XRD structure confirms the presence of only tetrabutylphosphonium cations and phenyltetrazolate anions in the unit cell with no solvent molecules or unaccounted void space. The butyl chains of the cation are arranged with all-trans conformations with no disorder reflecting the stability of the water-free solid-state structure, forming undulating layers in the unit cell (shown in Figure S10). Each cation participates in hydrogen-bonding to three anions (contacts less than the sum of the $\mathrm{VdW}$ radii, and $\mathrm{D}-\mathrm{H} \cdots \mathrm{A}$ angle $>130^{\circ}$ ) with the shortest hydrogen-bond contacts from C5 and C9 methylene sites adjacent to the central $P$-atom to the tetrazolate ring of the anions (Figure 2). Each anion accepts hydrogen-bonds from cations at all four N-sites.

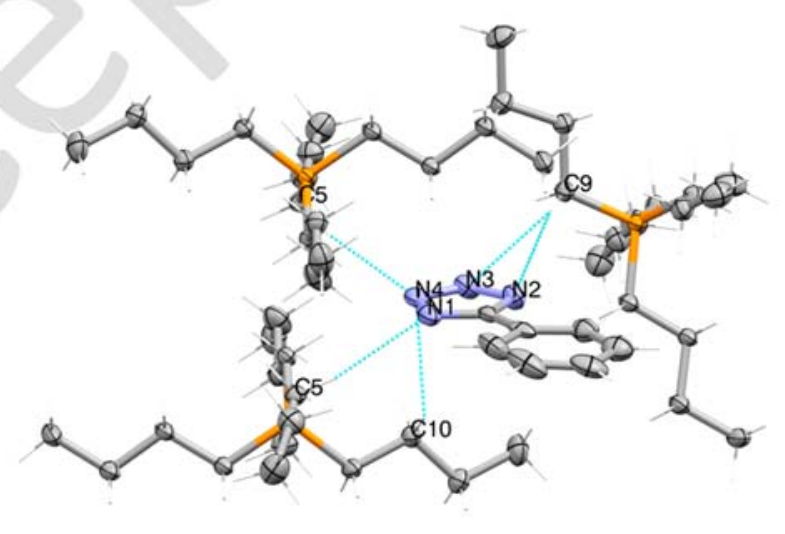

Figure 2. Principle hydrogen bonds found in the single crystal X-ray structure of $\left[\mathrm{P}_{4444}\right][\mathrm{Ph}$-tet] between methylene hydrogens on the phosphonium cation and to [Ph-tet] $]^{-}$anions. Each cation and each anion are involved in hydrogen bonding to three independent counter-ions. 
The relative hydrophobicity of this ionic liquid was evident during initial preparation of the ionic liquid, whereby biphasic mixtures could be generated by mixing moderately concentrated (ca. $0.5 \mathrm{M}$ ) aqueous solutions of the two starting components. A more detailed evaluation of the liquid-liquid equilibrium (LLE) and solid-liquid equilibrium (SLE) phase behavior of $\left[\mathrm{P}_{4444}\right][\mathrm{Ph}$-tet]/water mixtures was made as a function of temperature by visual inspection of samples placed in a thermostated Pyrex glass cell with magnetic stirring.
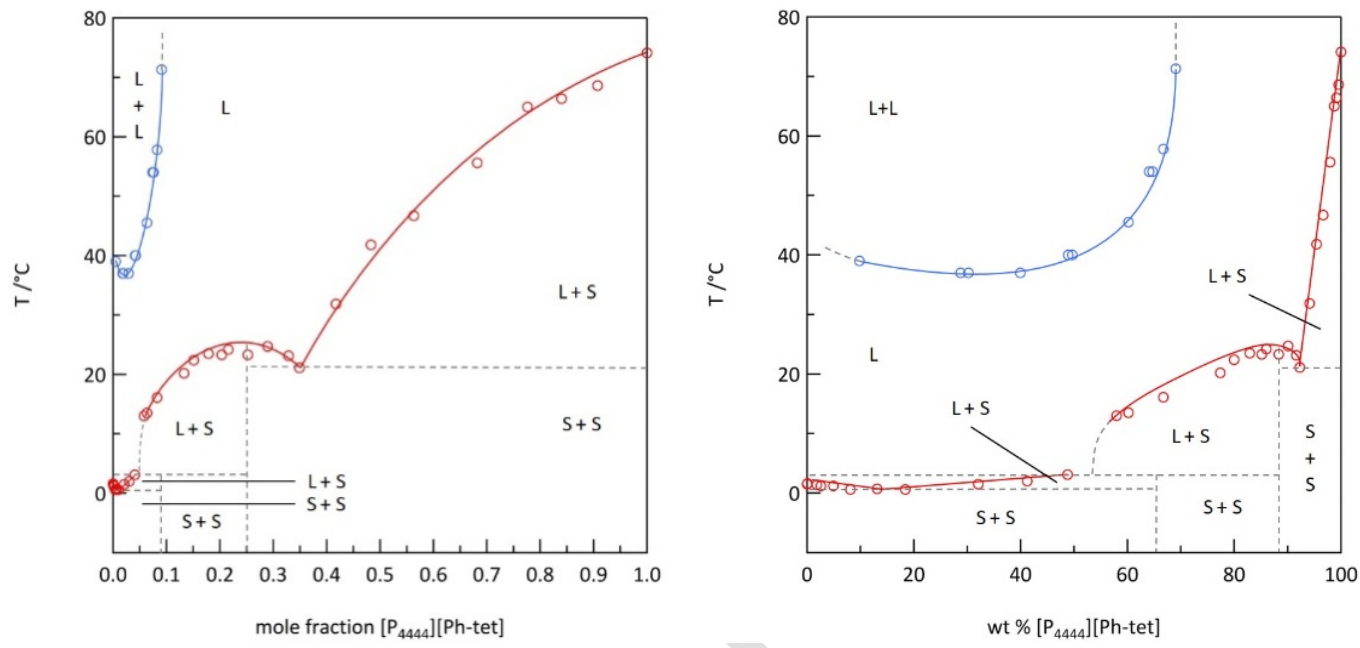

Figure 3. Temperature-composition phase diagrams for solutions of $\left[\mathrm{P}_{4444}\right][\mathrm{Ph}$-tet $]+\mathrm{H}_{2} \mathrm{O}$ as a function of the mole fraction (XIL) of IL in the mixture (top) and weight percentage of IL (bottom) showing the solid-liquid equilibria (red circles) and liquid-liquid equilibrium points (blue circles). Lines are drawn as visual aids.

The temperature-composition phase diagram plotted as both a function of mole fraction and weight percentage (wt\%) of IL (Figure 3) reveals both LLE and SLE transitions in the mixtures. Figure 3 shows the presence of a region of immiscibility between $\left[\mathrm{P}_{4444}\right][\mathrm{Ph}$-tet] and water where a liquid-liquid biphasic region with LCST behavior is observed above $37^{\circ} \mathrm{C}$ in mixtures containing up to ca. 0.1 mole fraction of ionic liquid (i.e. with more than $\sim 9$ water molecules for each $\left[\mathrm{P}_{4444}\right][\mathrm{Ph}$-tet]). This is consistent with the hydrophilicity index $(\mathrm{HI})$ concept introduced by Kohno and Ohno ${ }^{[11]}$ as an indicator of ionic liquid/water phase behavior. The $\mathrm{HI}$ is the number of moles of water per ionic liquid ion pair present at $60{ }^{\circ} \mathrm{C}$ in the ionic liquid-rich component of the liquid-liquid biphase, and Kohno and Ohno demonstrated that LCST behavior was only observed for ionic liquids having an $\mathrm{HI}$ of at least 7 . We determined the $\mathrm{HI}$ for $\left[\mathrm{P}_{4444}\right][\mathrm{Ph}$-tet]/water system by proton NMR spectroscopy to be 12 .

In the mole fraction phase diagram in Figure 3, the LLE region appears relatively small, however by reference to the mass fraction phase diagram (which compensates for the disparity in size between water and the ionic liquid) the true extent of this biphasic region is revealed with the two liquid phases occurring in mixtures containing up to $70 \mathrm{wt} \%\left[\mathrm{P}_{4444}\right][\mathrm{Ph}$-tet $]$. 
Formation of the biphasic region for $\left[\mathrm{P}_{4444}\right][\mathrm{Ph}$-tet]/water mixtures is a good indicator that the [Phtet] $]^{-}$anion is more hydrophobic than the $[\mathrm{Bz}]^{-}$isostere, $\left[\mathrm{P}_{4444}\right][\mathrm{Bz}]$ is completely miscible with water. Indeed, the LLE phase behavior of $\left[\mathrm{P}_{4444}\right]\left[\mathrm{Ph}\right.$-tet] appears to more closely resemble that of $\left[\mathrm{P}_{4444}\right][\mathrm{Sal}]$ which Ohno and co-workers previously noted was more hydrophobic than benzoate. ${ }^{[13]}$ Both $\left[\mathrm{P}_{4444}\right][\mathrm{Ph}-$ tet] and $\left[\mathrm{P}_{4444}\right][\mathrm{Sal}]$ exhibit LCST behavior over comparably wide composition ranges up to $65-70 \mathrm{wt} \%$ IL (Figure 4), although the LCST for $\left[\mathrm{P}_{4444}\right][\mathrm{Sal}]$ is ca. $10{ }^{\circ} \mathrm{C}$ lower than that for $\left[\mathrm{P}_{4444}\right][\mathrm{Ph}$-tet].

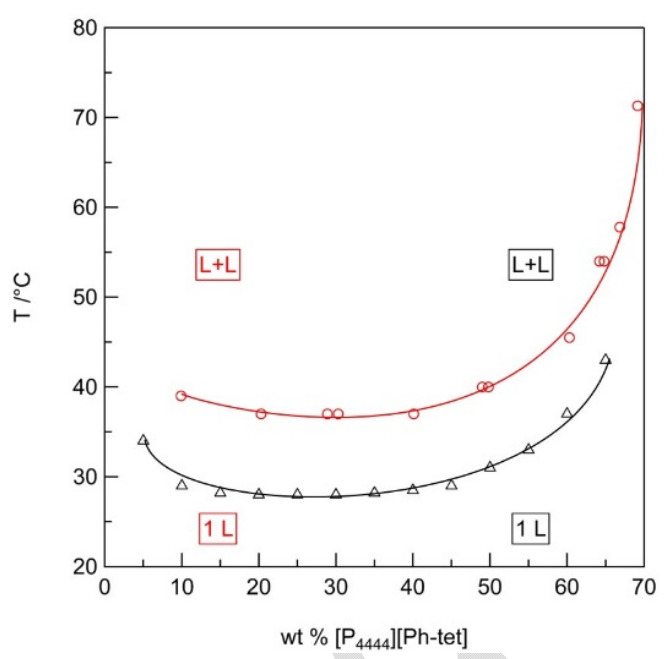

Figure 4. Comparison of liquid phase diagram for $\left[\mathrm{P}_{4444}\right][\mathrm{Ph}-$ tet $] /$ water (red circles) and $\left[\mathrm{P}_{4444]}\right][$ Sal $] /$ water ${ }^{[13]}$ (black triangles) plotted as weight percentage IL. Lines are drawn as visual aids.

Although IL/water systems exhibiting LCST phase-behavior are known, this behavior is much more common for ionic polymers whereas UCST behavior is more frequently observed for hydrophobic ILs. $^{[16,17]}$

LCST behavior is associated with a change from negative to positive Gibbs free energy $(\Delta G)$ of mixing ${ }^{[18]}$ and a negative entropy change $(\Delta S=-(\mathrm{d} \Delta \mathrm{G} / \mathrm{dT})) \cdot{ }^{[19]}$ As such, observation of LCST behavior is indicative of the formation of strong local interactions between the [Ph-tet] ${ }^{-}$anion and water molecules in the first solvation shell that are sufficient to generate discreet complexes and impose constraints on the solvated anion preventing random mixing.

Above the LCST, as the temperature is increased, the number of water molecules in the ionic liquidcontaining phase decreases (tie-line length increases). The $\mathrm{HI}$ measurement indicates there are 12 water molecules per ionic liquid ion-pair at $60{ }^{\circ} \mathrm{C}$ and observation of the right-hand region of the LLE curve shows the limiting phase composition at $75-80{ }^{\circ} \mathrm{C}$ is around $30 \mathrm{wt} \%$ (ca. 0.9 mol fraction) water. 
The full extent of water association with $\left[\mathrm{P}_{4444}\right][\mathrm{Ph}$-tet] and tendency to form complex hydrates was experimentally confirmed by measuring the SLE. We observed, for the first time, to best of our knowledge, both congruent and incongruent melting (peritectic behavior) and a eutectic point (Figure 3) for $\left[\mathrm{P}_{4444}\right][\mathrm{Ph}$-tet]/water mixtures. This is a clear indication of the formation of a number of discreet strong water-ionic liquid complexes over different compositions in the phase diagram.

Starting from pure $\left[\mathrm{P}_{4444}\right][\mathrm{Ph}$-tet] addition of small quantities of water resulted in a reduction in the melting point of the IL/water mixtures to $21^{\circ} \mathrm{C}$ at ca. 0.66 mole fraction of water added (ca. 1:2 ionic liquid:water). This is presumably an effect of partial dissolution and destabilization of the crystalline solvent-free salt on increasing water content. Reduction in melting points of ILs and other salts on addition or absorption of water is not unusual[3] and there are many examples where that form eutectics with water. ${ }^{[20]}$ Although, conversely, there are also many examples of organic salts and ILs that form congruent melting crystalline monohydrates ${ }^{[21]}$ or complex clathrates ${ }^{[22]}$ with water.

Rather than observing a single, simple eutectic point in the SLE, addition of further water (0.6-0.8 mole fraction) increased the SLE point to a local maximum at 0.25 mole faction IL ( $89 \%$ wt $\%)$ at $24{ }^{\circ} \mathrm{C}$. Cooling a 0.2 mole fraction $\left[\mathrm{P}_{4444}\right]\left[\mathrm{Ph}\right.$-tet] solution to $20^{\circ} \mathrm{C}$ resulted in the formation of colorless crystals which were identified as $\left[\mathrm{P}_{4444}\right]\left[\mathrm{Ph}\right.$-tet] $\cdot 3 \mathrm{H}_{2} \mathrm{O}$ by single crystal $X R D$. This confirms that the local stabilization of the trihydrate complex with three water molecules contributing to first shell hydrogenbonding to the anion.

$\left[\mathrm{P}_{4444}\right][\mathrm{Ph}$-tet $] \cdot 3 \mathrm{H}_{2} \mathrm{O}$ displays very different ion association and hydrogen-bonding motifs in the crystal structure to those of anhydrous $\left[\mathrm{P}_{4444}\right][\mathrm{Ph}$-tet]. There are no direct cation $\cdots$ anion hydrogenbonding interactions and, instead, water molecules completely replace the cations as hydrogen-bond donors to the anion tetrazolate $\mathrm{N}$-sites (Figure 5).

Each $\mathrm{N}$-site on the anion is involved in a single, hydrogen-bond to a water molecule forming catenar chains of water-linked anions. Interestingly there is an asymmetry in the hydrogen-bonding network about the anion. On one side, two water molecules form two bridging hydrogen-bonds between anions arranged head-to-tail. On the other side of each anion, four water molecules form a rectangle that bridges between anions via four hydrogen-bonds, with each water molecule contributing a single hydrogen bond to a tetrazolate- $\mathrm{N}$ site and two to the adjacent water molecules in the rectangular cluster. All $\mathrm{N} \cdots \mathrm{O}$ and $\mathrm{O} \cdots \mathrm{O}$ distances (average 2.89 and $2.87 \AA$ respectively) are within the expected ranges for hydrogen bonds. The association of the three water molecules with each [Ph-tet] $]^{-}$anion in the trihydrate structure provides four hydrogen-bonds to each tetrazolate anion, whereas in the pure $\left[\mathrm{P}_{4444}\right][\mathrm{Ph}$-tet] six hydrogen-bonds to the anion are present and these include a greater cation $\cdots$ anion contributions that probably account for the increased overall stability of the anhydrous solid state. 


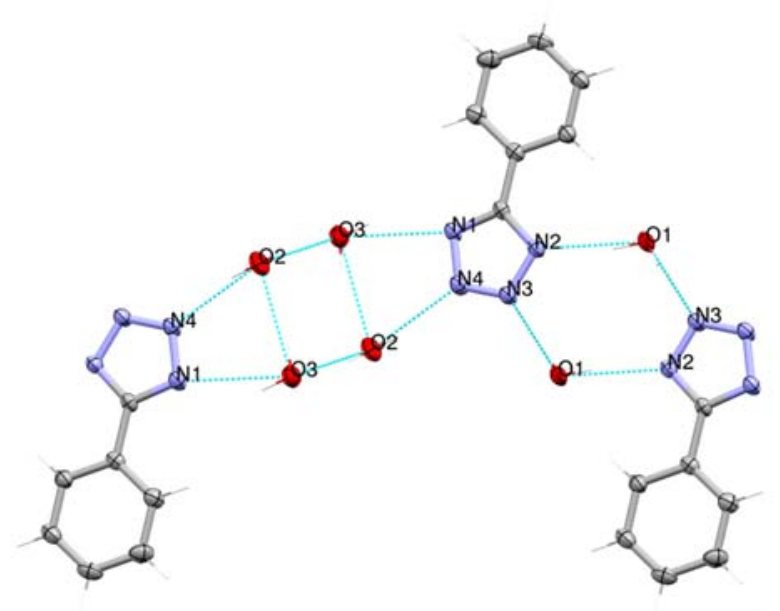

Figure 5. The water-anion hydrogen bonding motif in the single crystal structure of $\left[\mathrm{P}_{4444}\right][\mathrm{Ph}$-tet $] \cdot 3 \mathrm{H}_{2} \mathrm{O}$. Two bridging water molecules link anions into a two-anion, two-water dimer $(\mathrm{N} \cdots \mathrm{O}=2.85,2.90 \AA)$ and these are connected forming ribbons through four water rectangles $(\mathrm{N} \cdots \mathrm{O}=2.85,2.93 \AA$ and $\mathrm{O} \cdots \mathrm{O}=2.85,2.86 \AA)$.

In addition to the trihydrate, which is stable up to the melting point $\left(24{ }^{\circ} \mathrm{C}\right)$ and was crystallographically characterized, a second hydrate is also observed at lower temperature and higher water content. This undergoes a peritectic reaction at $3{ }^{\circ} \mathrm{C}$, transforming into the trihydrate, for compositions close to 0.049 mole fraction of IL ( $54 \mathrm{wt} \%)$. Solid samples prepared at compositions with a higher IL content than this can be observed to undergo a transformation through initial melting at $3{ }^{\circ} \mathrm{C}$ followed by rapid formation of crystals that subsequently melt at $13^{\circ} \mathrm{C}$. A further eutectic point, with a small suppression of the water freezing temperature (Figure S7), is also observed with 0.007 IL mole fraction ( $13 \mathrm{wt} \% \mathrm{IL})$. Unfortunately, it was not possible to isolate and identify the stoichiometry of the second hydrate of $\left[\mathrm{P}_{4444}\right][\mathrm{Ph}$-tet] here due to the very small temperature range where this phase is present in co-existence with liquid $\left(0-3^{\circ} \mathrm{C}\right)$. However, we determined that the second hydrate is only present in co-existence with liquid for mixtures with composition between $54 \mathrm{wt} \%$ and $63 \mathrm{wt} \%$ of IL using DSC. Two peaks were observed, indicative of the transition, in this temperature range only up to $63 \mathrm{wt} \%$ IL. For compositions outside of this range only one peak was observed. This result suggests that this second hydrate contains at least 12 molecules of water per ion pair.

It is worth noting that the $\mathrm{HI}$ value for the IL-rich phase in the LLE also revealed 12 water molecules per IL ion-pair, and it is interesting to speculate on potential relationships and conservation of solid state hydration patterns into the liquid phase. Many tetraalkylammonium and phosphonium salts form solid hydrates with hydration numbers as large as $80 .{ }^{[22]}$ These solids have porous structures in which the anions are incorporated in the water hydrogen-bonded network and the cations locate within cavities. ${ }^{[23]}$ It is therefore not surprising that the second $\left[\mathrm{P}_{4444]}\right][\mathrm{Ph}$-tet] hydrate phase 
appears to be a semiclathrate hydrate containing an excess of water. An indication of the potential to expand the hydration number of $\left[\mathrm{P}_{4444}\right][\mathrm{Ph}$-tet] can be seen from the presence of the two different ways in which water molecules link between anions in the trihydrate (Figure 5) with water-bridged hydrogenbonds transforming into anion-linked water clusters.

\section{Conclusions}

Overall, we set out to examine whether novel ILs could be generated using (bio)isostere concepts to identify anions with controllable, and ideally increased, hydrophobicity compared to carboxylate anions, here using 5-phenyltetrazolate as a substitute for benzoate. In $\left[\mathrm{P}_{4444}\right]\left[\mathrm{Ph}\right.$-tet], the $[\mathrm{Ph} \text {-tet] }]^{-}$anion and water molecules interact strongly forming hydrates that yield SLE phase behavior that resembles that of hydrate-forming inorganic salts like magnesium nitrate ${ }^{24}$ with both eutectic and peritectic points and the formation of multiple salt hydrates. Water-anion association and complexation in the liquid phase is also evident, with LCST-phase behavior in water across a wide composition range. The liquid-liquid behavior (with an LCST point) is more closely analogous to that of $\left[\mathrm{P}_{4444}\right][$ Sal] rather than that of the more hydrophilic isostere benzoate that is completely miscible with water.

We have demonstrated that the extensive portfolio of pharmacophore replacements of carboxylic acids can be used to identify functional anion targets for IL design with interesting opportunities to control both hydrophobic and hydrophilic phase behavior. Given the interest in using thermo-responsive ILs for separations processes, ${ }^{[, 10]}$ and the diverse uses of ILs with both carboxylate $^{[25-27]}$ and tetrazolate ${ }^{[28,29]}$ anions, there appear to be many opportunities to productively exploit these anion relationships.

\section{Acknowledgments}

This project has received funding from the European Union's Horizon 2020 research and innovation programme under grant agreement No. 655334.

‡ Experimental methods, crystal structure data, and thermophysical characterization data is available as SI. CCDC 1566594 and 1566595 contain the supplementary crystallographic data for this paper. These data are provided free of charge by The Cambridge Crystallographic Data Centre.

\section{Experimental Section}

Tetrabutylphosphonium hydroxide $\left(40 \%\right.$ wt in $\left.\mathrm{H}_{2} \mathrm{O}\right)$ and 5-phenyl- $1 \mathrm{H}$-tetrazole $(95 \%)$ were purchased from Fluorochem. Tetrabutylphosphonium 5-phenyl-tetrazolate ([P $\left.{ }_{4444]}\right][\mathrm{Ph}$-tet $\left.]\right)$ was prepared by 
neutralization of tetrabutylphosphonium hydroxide, $\left[\mathrm{P}_{4444}\right][\mathrm{OH}]\left(40 \%\right.$ wt in $\left.\mathrm{H}_{2} \mathrm{O}, 60.005 \mathrm{~g}, 0.0868 \mathrm{~mol}\right)$ at $60{ }^{\circ} \mathrm{C}$ with 5-phenyl-1H-tetrazole $(12.691 \mathrm{~g}, 0.0868 \mathrm{~mol})$, resulting in formation of two phases. The prepared IL was extracted with ethyl acetate and washed with water several times. The IL was dried under reduced pressure for at least $24 \mathrm{~h}$. Full characterization is provided in the SI.

Microanalyses and electrospray MS were performed by ASEP, Queen's University Belfast. ${ }^{1} \mathrm{H},{ }^{13} \mathrm{C}$ and ${ }^{31} \mathrm{P}$ NMR spectroscopy in DMSO- $d_{6}$ using a Bruker Avance III $400 \mathrm{MHz}$ spectrometer. FT-IR spectra were performed using a PerkinElmer Spectrum 100 ATR FT-IR spectrometer. The melting point for pure $\left[\mathrm{P}_{4444}\right][\mathrm{Ph}$-tet] was determined by differential scanning calorimetry (TA DSC Q2000 with a refrigerated cooling system, 5-20 mg samples, $1^{\circ} \mathrm{C} \mathrm{min}-1$ heating and cooling rates under dinitrogen, scanning between -100 and $+100{ }^{\circ} \mathrm{C}$ ). The decomposition temperature of $\left[\mathrm{P}_{4444}\right][\mathrm{Ph}$-tet] was measured in the dynamic heating regime using a TA Instruments Q5000 TGA instrument under nitrogen atmosphere. Samples were heated from room temperature to $500{ }^{\circ} \mathrm{C}$ under constant heating rate of $10{ }^{\circ} \mathrm{C} \mathrm{min}^{-1}$.

All LLE measurements (cloud-point determinations) on the temperature-composition phase diagrams were performed using visual detection in a Pyrex glass cell with magnetic stirring. The samples were prepared in the cells using an analytical balance $(0.1 \mathrm{mg})$. The cells were then immersed in a thermostatic bath. The solutions were heated, usually in two or three consecutive runs with the two last runs being carried out at a rate of around $2^{\circ} \mathrm{C} \mathrm{h}^{-1}$ near the cloud point temperature. Starting from the homogeneous region, the temperature at which the first sign of turbidity appeared upon heating was taken as the temperature of the liquid-liquid phase transition. The mixtures used for the determination of the SLE were prepared in the same manner as the LLE samples and the detection of phase change was also performed visually in a Pyrex glass cell. The cell was then inserted in a thermostatic water or acetone bath and cooled by adding ice or liquid nitrogen. After solidification, the samples were heated very slowly $\left(2^{\circ} \mathrm{C} \mathrm{h}^{-1}\right)$ with continuous stirring inside the cell during the melting process. The temperature at which the last crystal disappeared was taken as the temperature of the solid-liquid equilibrium (data shown in Table S1).

Both the crystal disappearance temperatures and the cloud point temperatures were measured using an insulated wire miniature type $\mathrm{K}$ thermocouple model $5 \mathrm{SC}$ coupled with a $\mathrm{HH} 802 \mathrm{U}$ thermocouple thermometer, with an expected measurement uncertainty of $\pm 1.5^{\circ} \mathrm{C}$. The measurement uncertainty resulting from the visual observation of the phase transitions is expected to be greater than the instrumental error.

Single-crystal X-ray diffraction was determined using fragments of crystal obtained from slow cooling of molten $\left[\mathrm{P}_{4444}\right]\left[\mathrm{Ph}\right.$-tet] ionic liquid and a 0.2 mole fraction solution of $\left[\mathrm{P}_{4444}\right][\mathrm{Ph}$-tet] in water respectively. Data was collected using a SuperNova, Dual, Cu, EosS2 diffractometer. The crystals were kept at $100(2) \mathrm{K}$ during data collection. Using Olex2, ${ }^{[30]}$ the structures were solved with the ShelXT${ }^{[31]}$ structure solution program using Intrinsic Phasing and refined with the ShelXL ${ }^{[31]}$ refinement package using least 
squares minimization. Non-hydrogen atom positions were fully refined using anisotropic thermal parameters and the hydrogen atoms were initially located at idealized positions and then refined using riding coordinates. Details of the crystal data and structure determination of $\left[\mathrm{P}_{4444}\right][\mathrm{Ph}$-tet] and $\left[\mathrm{P}_{4444}\right]\left[\mathrm{Ph}\right.$-tet] $3 \mathrm{H}_{2} \mathrm{O}$ are given in the SI.

Keywords: liquid-liquid equilibria • solid-liquid equilibria • ionic liquids

[1] J. G. Huddleston, H. D. Willauer, R. P. Swatloski, A. E. Visser, R. D. Rogers, Chem. Commun. 1998, $1765-1766$

[2] M. D. Joshi, J. L. Anderson, RSC Adv. 2012, 2, 5470-5484.

[3] K. R. Seddon, A. Stark, M.-J. Torres, Pure Appl. Chem. 2000, 72, 2275-2287.

[4] R. P. Swatloski, J. D. Holbrey, R. D. Rogers, Green Chem., 2003, 5, 361-363.

[5] F. Endres and S. Z. El Abedin, Phys. Chem. Chem. Phys., 2006, 8, 2101-2116.

[6] P. Bonhôte, P. A. P. Dias, M. Armand, N. Papageorgiou, K. Kalyanasundaram, M. Graetzel, Inorg. Chem. 1996, 35, 1168-1178.

[7] N. V. Ignat'ev, U. Welz-Biermann, A. Kucheryna, G. Bissky, H. Willner, J. Fluor. Chem. 2005, 126, 1150-1159.

[8] K. E. Gutowski, G. A. Broker, H. D. Willauer, J. G. Huddleston, R. P. Swatloski, J. D. Holbrey, R. D. Rogers, J. Am. Chem. Soc. 2003, 126, 6632-6633; M. G. Freire, A. F. M. Cláudio, J. M. M. Araújo, J. A. P. Coutinho, I. M. Marrucho, J. N. Canongia Lopes, L. P. N. Rebelo, Chem. Soc. Rev. 2012, 41, 49664995.

[9] J. R. Trindade, Z. P. Visak, M. Blesic, I. M. Marrucho, J. A. P. Coutinho, J. N. C. Lopes, L. P. N. Rebelo, J. Phys. Chem. B 2007, 111 , 4737-4741.

[10] Y. Qiao, W. Ma, N. Theyssen, C. Chen, Z. Hou, Chem. Rev. 2017, 117, 6881-6928; H. Passos, A. Luis, J. A. P. Coutinho, M. G. Freire, Sci. Rep. 2016, 6, 20276.

[11] Y. Kohno and H. Ohno, Chem. Commun. 2012, 48, 7119-7130.

[12] S. Saita, Y. Kohno, N. Nakamura, H. Ohno, Chem. Commun. 2013, 49, 8988-8990; Y. Kohno, H. Ohno, Phys. Chem. Chem. Phys. 2012, 14, 5063-5070.

[13] T. Ando, Y. Kohno, N. Nakamura, H. Ohno, Chem. Commun. 2013, 49, 10248-10250.

[14] B. C. Ballatore, D. M. Huryn, A. B. Smith, ChemMedChem. 2013, 8, 385-395.

[15] F. H. Allen, C. R. Groom, J. W. Liebeschuetz, D. A. Bardwell, T. S. G. Olsson, P. A. Wood, J. Chem. Inf. Model. 2012, 52, 857-866.

[16] Y. Zhao, H. Wang, Y. Pei, Z. Liu, J. Wang, Phys. Chem. Chem. Phys. 2016, 18, 23238-23245.

[17] Y. Qiao, W. Ma, N. Theyssen, C. Chen, Z. Hou, Chem. Rev. 2017, 117, 6881-6928.

[18] H. Renon and J. M. Prausnitz, AlChE J. 1968, 14, 135-144; D. Balasubramanian and P. Mitra, J. Phys. Chem. 1979, 83, 2724-2727.

[19] J. L. Copp and D. H. Everett, Discuss. Faraday Soc. 1953, 15, 174.

[20] For example, U. Domańska and R. Bogel-Łukasik, J. Phys. Chem. B. 2005, 109, 12124-12132; T. M. Letcher, D. Ramjugernath, K. Tumba, M. Krolikowski, U. Domańska, Fluid Phase Equilibr. 2010, 294, 89-97; U. Domańskaa, M. Krolikowskaa, K. Paduszyński, Fluid Phase Equilibr. 2011, 303, 1-9; M. Królikowska, M. Karpińska, M. Zawadzki, Fluid Phase Equilibr. 2013, 354, 66-74; A. A. Strechan, Y. U. Paulechka, A. G. Kabo, A. V. Blokhin, G. J. Kabo, J. Chem. Eng. Data 2007, 52, 1791-1799.

[21] A. E. Bradley, C. Hardacre, J. D. Holbrey, S. Johnston, S. E. J. McMath, M. Nieuwenhuyzen, Chem. Mater. 2002, 14, 629-635; R. P. Swatloski, J. D. Holbrey, R. D. Rogers, Green Chem. 2003, 5, 361-363.

[22] D. L. Fowler, W. V. Loebenstein, D. B. Pall, C. A. Kraus, J. Am. Chem. Soc. 1940, 62, 1140-1142; R. McMullan, G. A. Jeffrey, J. Chem. Phys. 1959, 31, 1231-1234; H. Nakayama, C. Hayashi, Thermochim. Acta. 1995, 253, 77-84.

[23] D. W. Davidson, in Water - A Comprehensive Treatise, Vol. 7 (Ed.: F. Franks), Plenum Press, New York, 1982, Chap. 3, p. 115; G. A. Jeffrey, Hydrate Inclusion Compounds, in Inclusion Compounds 1, (Eds.: J. L. Atwood, J. E. D. Davis, D. D. MacNichol), Academic Press, London, 1983 , p 135.

[24] W. W. Ewing, J. D. Brandner, C. B. Slichter, W. K. Griesinger, J. Am. Chem. Soc. 1933, 55, 4822-4824.

[25] E. Boros, M. J. Earle, M. A. Gilea, A. Metlen, A.-V. Mudring, F. Rieger, A. J. Robertson, K. R. Seddon, A. A. Tomaszowska, L. Trusov, J. S. Vyle, Chem. Commun. 2010, 46, 716-718; H. Rodriguez, G. Gurau, J. D. Holbrey, R. D. Rogers, Chem. Commun. 2011, 47, $3222-3224$

[26] A. Brandt, J. Gräsvik, J. P. Hallett, T. Welton, Green Chem. 2013, 15, 550-583.

[27] H. Garcia, R. Ferreira, M. Petkovic, J. L. Ferguson, M. C. Leitão, H. Q. N. Gunaratne, K. R. Seddon, L. P. N. Rebelo, C. S. Pereira, Green Chem. 2010, 12, 367-369.

[28] S. Seo, M. Quiroz-Guzman, M. A. DeSilva, T. B. Lee, Y. Huang, B. F. Goodrich, W. F. Schneider, J. F. Brennecke, J. Phys. Chem. B 2014, 118, 5740-5751.

[29] A. R. Katritzky, S. Singh, K. Kirichenko, M. Smiglak, J. D. Holbrey, W. M. Reichert, S. K. Spear, R. D. Rogers, Chem. Eur. J. 2006, 12, 4630-4641.

[30] O. V. Dolomanov, L. J. Bourhis, R. J. Gildea, J. A. K. Howard, H. Puschmann, J. Appl. Cryst. 2009, 42, $339-341$.

[31] G. M. Sheldrick, Acta Cryst. A 2015, 71, 3-8. 


\section{Graphical Abstract}

The ionic liquid,

tetrabutylphosphonium

5-phenyltetrazolate, exhibits both LCST-phase behavior and extensive solid-liquid equilibria with water including formation of eutectic and peritectic hydrate salts

\section{Anion hydration drives LCST}

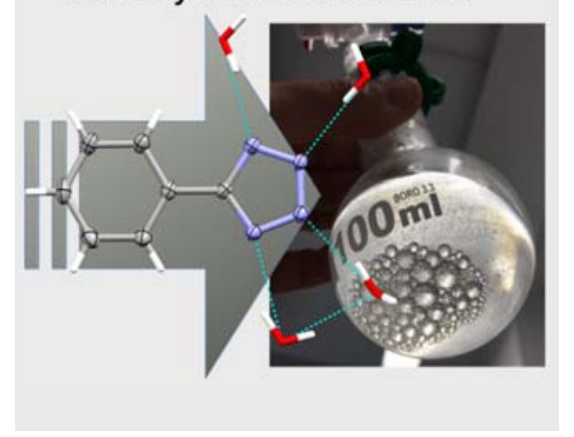

Leila Moura, Lucy C. Brown, Marijana Blesic and John D. Holbrey*

LCST-phase behavior and complexation with water of an ionic liquid incorporating the

5-phenyltetrazolate anion 


\title{
Supplementary Information
}

\section{LCST-phase behavior and complexation with water of a new ionic liquid incorporating the 5-phenyltetrazolate anion}

\author{
Leila Moura, ${ }^{[a]}$ Lucy C. Brown, ${ }^{[a]}$ Marijana Blesic ${ }^{[a]}$ and John D. Holbrey ${ }^{*}[a]$
}

\section{Experimental}

Tetrabutylphosphonium hydroxide $\left(40 \%\right.$ wt in $\left.\mathrm{H}_{2} \mathrm{O}\right)$ and 5-phenyl- $1 \mathrm{H}$-tetrazole $(95 \%)$ were purchased from Fluorochem. The ionic liquid tetrabutylphosphonium 5-phenyl-tetrazolate ([P $\mathrm{P}_{4444]}[\mathrm{Ph}$-tet] $)$ was prepared by neutralization of the corresponding hydroxide, $\left[\mathrm{P}_{4444}\right][\mathrm{OH}]\left(40 \%\right.$ wt in $\mathrm{H}_{2} \mathrm{O}, 60.005 \mathrm{~g}$, $0.0868 \mathrm{~mol})$ at $60{ }^{\circ} \mathrm{C}$ with 5-phenyl- $1 \mathrm{H}$-tetrazole $(12.691 \mathrm{~g}, 0.0868 \mathrm{~mol})$, resulting in formation of two phases. The prepared IL was extracted with ethyl acetate and washed with water several times. The IL was dried under reduced pressure for at least $24 \mathrm{~h}$.

Compared to the ${ }^{1} \mathrm{H}$ and ${ }^{13} \mathrm{C}$ NMR spectra of 5-phenyltetrazole (Figure S1) the ${ }^{1} \mathrm{H}$ and ${ }^{13} \mathrm{C}$ NMR spectra of $\left[\mathrm{P}_{4444}\right][\mathrm{Ph}$-tet] in Figure $\mathbf{S 2}$ confirm successful deprotonation of 5-phenyl-tetrazole forming the tetrazolate anion, indicated by loss of the down field tetrazole $\mathrm{N}-\mathrm{H}$ signal at $16.78 \mathrm{ppm}$ present in the starting material. No signals attributable to water or hydroxide ions in the ionic liquid were observed in the ${ }^{1} \mathrm{H}$ NMR spectrum. The corresponding ${ }^{31} \mathrm{P}$ NMR of the IL (Figure S3) also shows only a single phosphorous environment with a chemical shift of $33.5 \mathrm{ppm}$.

FT-IR spectra (Figure S4) also support deprotonation of the anion precursor for $\left[\mathrm{P}_{4444}\right][\mathrm{Ph}$-tet] by the disappearance of the broad and complex but characteristic $\mathrm{N}-\mathrm{H}$ vibration bands ${ }^{[1]}$ between 3500 and $2300 \mathrm{~cm}^{-1}$ from 1-phenyl-tetrazole in $\left[\mathrm{P}_{4444}\right]\left[\mathrm{Ph}\right.$-tet]. The strong bands between 3000 and $2870 \mathrm{~cm}^{-1}$ are due to alkyl $\mathrm{C}-\mathrm{H}$ stretches of the butyl groups in the phosphonium cation and can therefore be observed in both phosphonium based ionic liquids $\left[\mathrm{P}_{4444}\right][\mathrm{Ph}-\mathrm{tet}]$ and $\left[\mathrm{P}_{4444}\right][\mathrm{Cl}]$. Stretching vibrations corresponding to the phenyl ring can also be observed in the spectra of both $\left[\mathrm{P}_{4444}\right][\mathrm{Ph}$-tet] and 5phenyl-tetrazole between 3100 and $3000 \mathrm{~cm}^{-1}$.

Neat $\left[\mathrm{P}_{4444}\right][\mathrm{Ph}$-tet] was isolated initially as a liquid that undergoes a slow transformation to a crystalline solid. Differential scanning calorimetry performed on a solid sample (Figure S5) shows the presence of an exothermic solid-solid phase transition at $9.5^{\circ} \mathrm{C}\left(T_{\text {onset }} 8.9^{\circ} \mathrm{C}, \Delta H 7.1 \mathrm{~kJ} / \mathrm{mol}\right)$ followed by melting at $75.3^{\circ} \mathrm{C}\left(T_{\text {onset }} 72.5{ }^{\circ} \mathrm{C}, \Delta H 18.6 \mathrm{~kJ} / \mathrm{mol}\right)$. There was a significant kinetic barrier on cooling to recrystallization and no transitions were observed in cooling cycles by DSC, even at $1{ }^{\circ} \mathrm{C} / \mathrm{min}$ cooling rate. The melting point identified by DSC was confirmed visually by observation $74.1^{\circ} \mathrm{C}$. The IL 
shows moderate thermal stability. Thermal decomposition, measured under dynamic heating at a constant $10{ }^{\circ} \mathrm{C} \mathrm{min}-1$ by TGA followed a single step pathway starting at around $275^{\circ} \mathrm{C}$ (Figure S6).
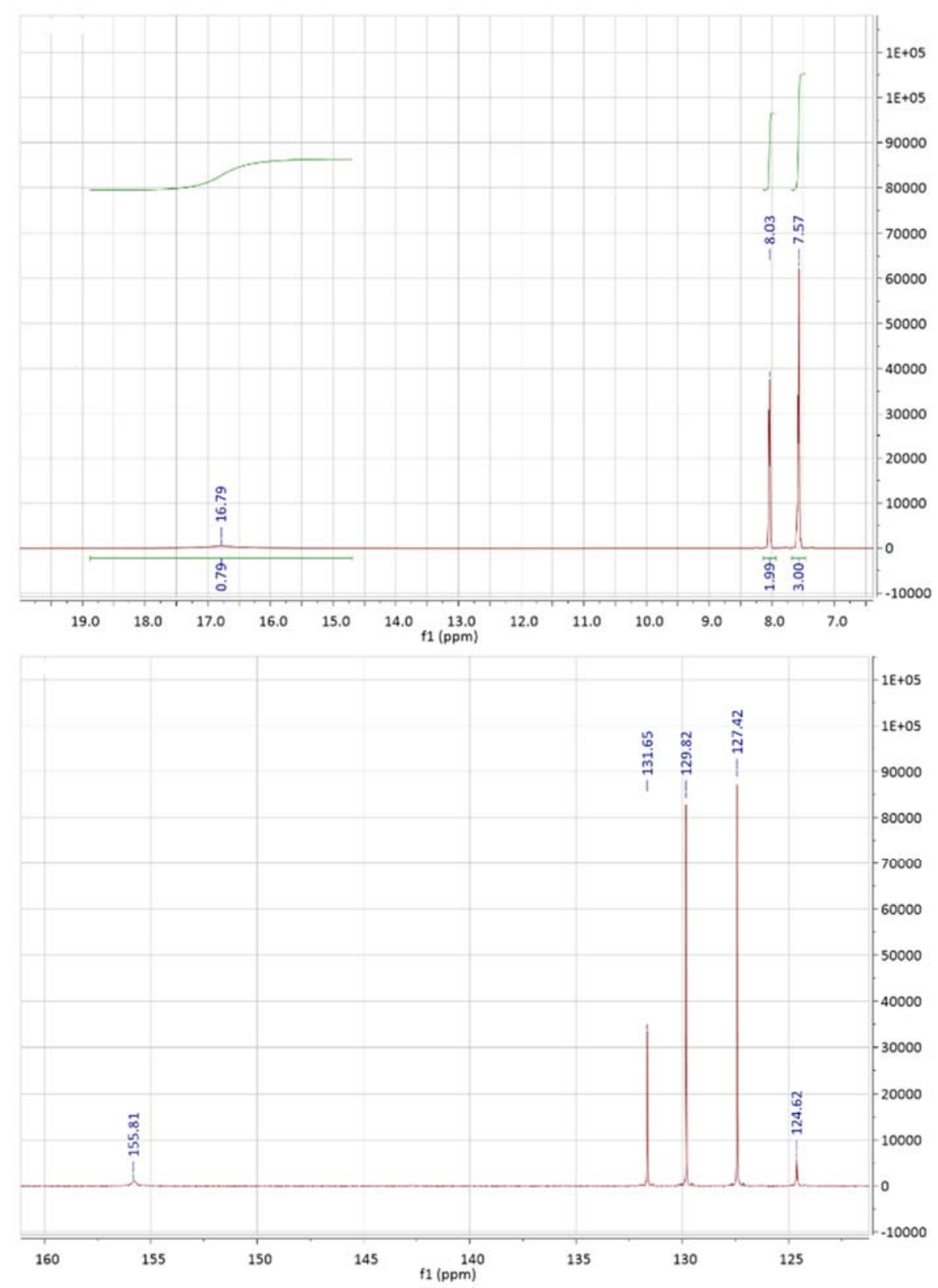

Figure S1. 5-phenyl-tetrazole $\delta{ }^{1} \mathrm{H}\left(400 \mathrm{MHz}\right.$; DMSO- $\left.d_{6}\right)$ : $16.79(1 \mathrm{H}, \mathrm{N}-\mathrm{H}$, tetrazole ring), 8.03-7.57 $\left(5 \mathrm{H}, 2\right.$ peaks, phenyl ring). ${ }^{13} \mathrm{C}\left(100.55 \mathrm{MHz}\right.$; DMSO- $\left.d_{6}\right)$ : 155.81 ( $\left.\mathrm{N}-\mathrm{C}-\mathrm{N}\right), 131.65-124.62$ (4 peaks, phenyl ring). 

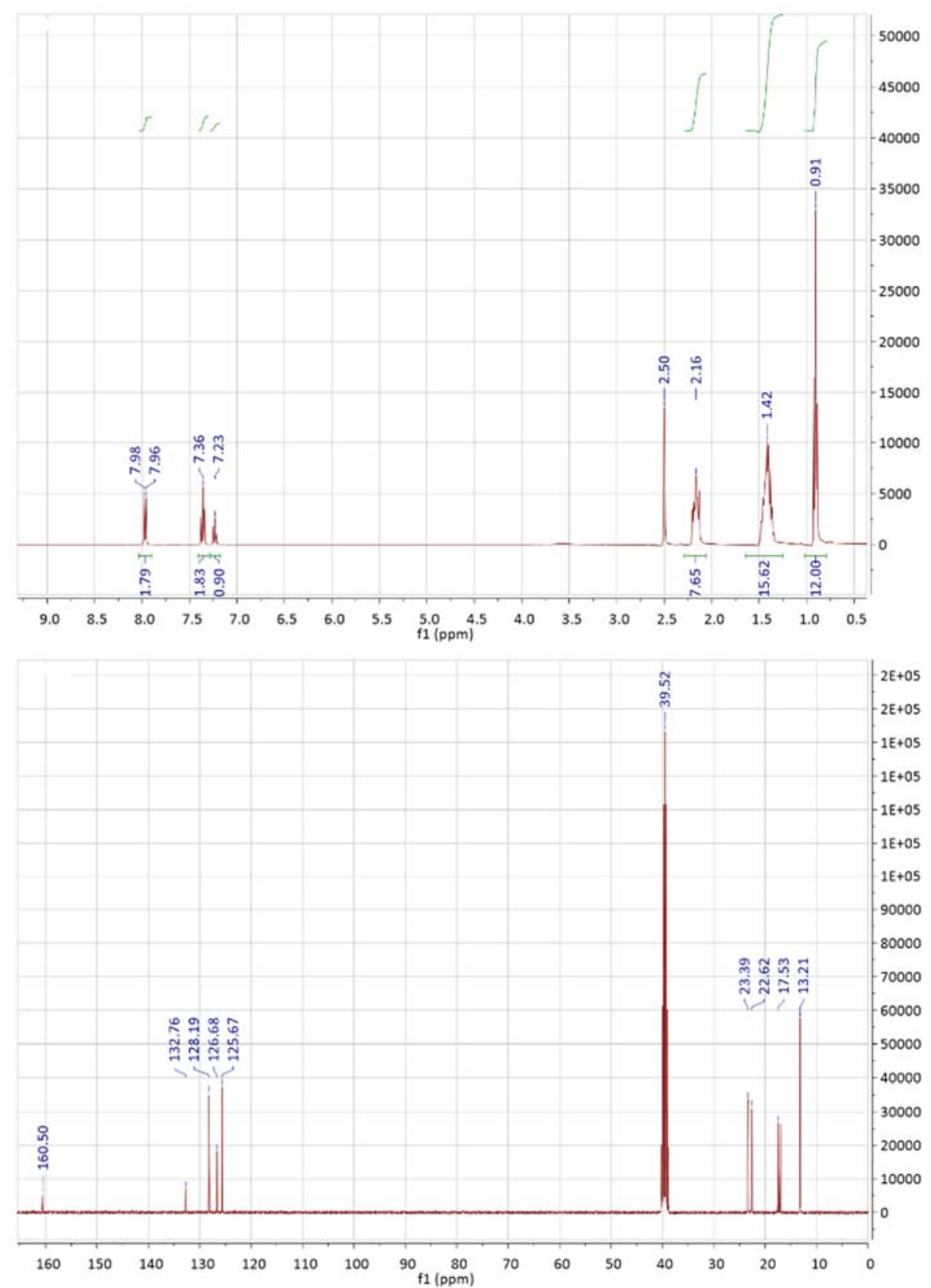

Figure S2. $\left[\mathrm{P}_{4444}\right]\left[\mathrm{Ph}\right.$-tet] $\delta{ }^{1} \mathrm{H}\left(400 \mathrm{MHz}\right.$; DMSO- $\left.d_{6}\right):$ 7.98-7.23 (5H, 3 peaks, phenyl ring), $2.16(8 \mathrm{H}, \mathrm{m}$, P- $\left.\mathrm{CH}_{2}-\mathrm{CH}_{2}-\mathrm{CH}_{2}-\mathrm{CH}_{3}\right), 1.38\left(16 \mathrm{H}, \mathrm{m}, \mathrm{P}-\mathrm{CH}_{2}-\mathrm{CH}_{2}-\mathrm{CH}_{2}-\mathrm{CH}_{3}\right), 0.87\left(12 \mathrm{H}, \mathrm{m}, \mathrm{P}-\mathrm{CH}_{2}-\mathrm{CH}_{2}-\mathrm{CH}_{2}-\mathrm{CH}_{3}\right) . \delta$ ${ }^{13} \mathrm{C}\left(100.55 \mathrm{MHz}\right.$; DMSO- $d_{6}$ ): 160.53 (N-C-N), 132.73-125.56 (4 peaks, phenyl ring), 23.31 (doublet, $\mathrm{P}-\mathrm{CH}_{2}-\mathrm{CH}_{2}-\mathrm{CH}_{2}-\mathrm{CH}_{3}$ ), 22.62 (doublet, P- $\mathrm{CH}_{2}-\mathrm{CH}_{2}-\mathrm{CH}_{2}-\mathrm{CH}_{3}$ ), 17.50 (doublet, $\mathrm{P}-\mathrm{CH}_{2}-\mathrm{CH}_{2}-\mathrm{CH}_{2}-\mathrm{CH}_{3}$ ), $13.06\left(\mathrm{P}_{-}-\mathrm{CH}_{2}-\mathrm{CH}_{2}-\mathrm{CH}_{2}-\mathrm{CH}_{3}\right)$. 


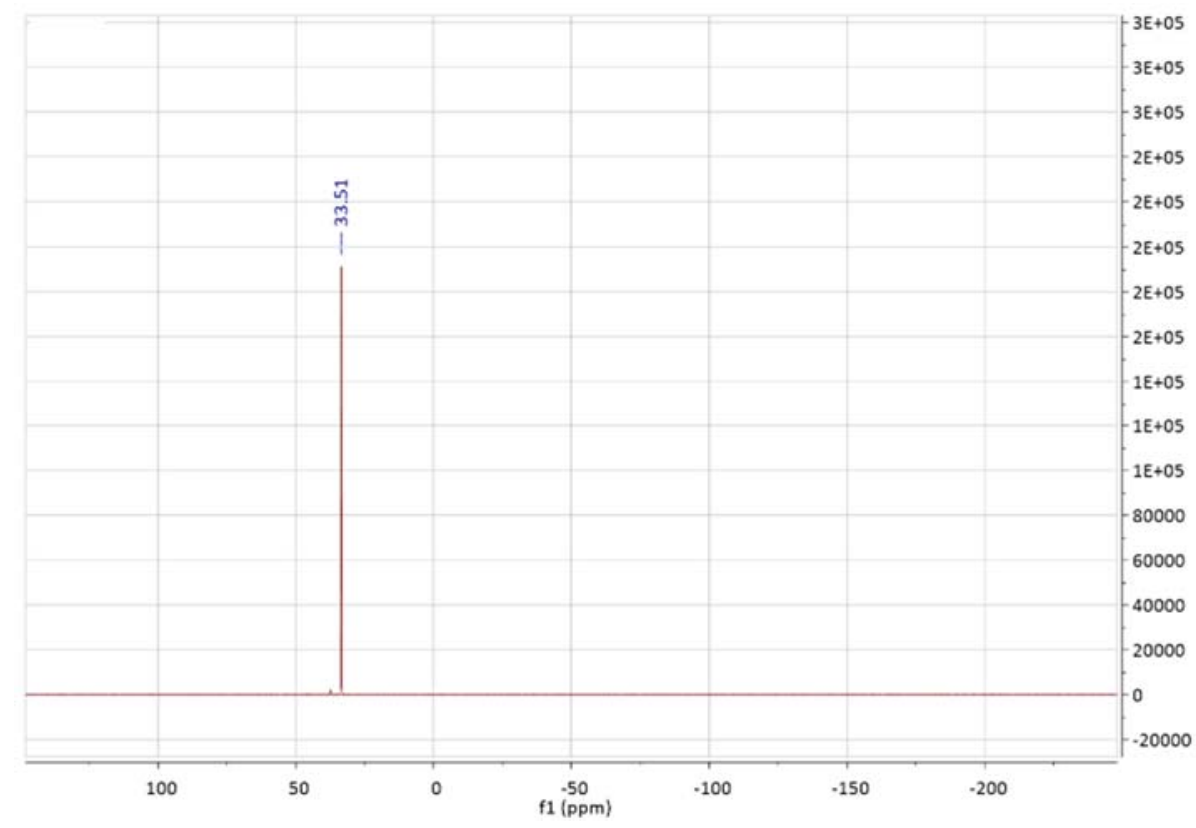

Figure S3. $\left[\mathrm{P}_{4444}\right][\mathrm{Ph}-\mathrm{tet}] \delta{ }^{31} \mathrm{P}\left(161.88 \mathrm{MHz}\right.$; DMSO-d $\left.\mathrm{d}_{6}\right): 33.51\left(\mathrm{P}-\mathrm{CH}_{2}-\mathrm{CH}_{2}-\mathrm{CH}_{2}-\mathrm{CH}_{3}\right)$.

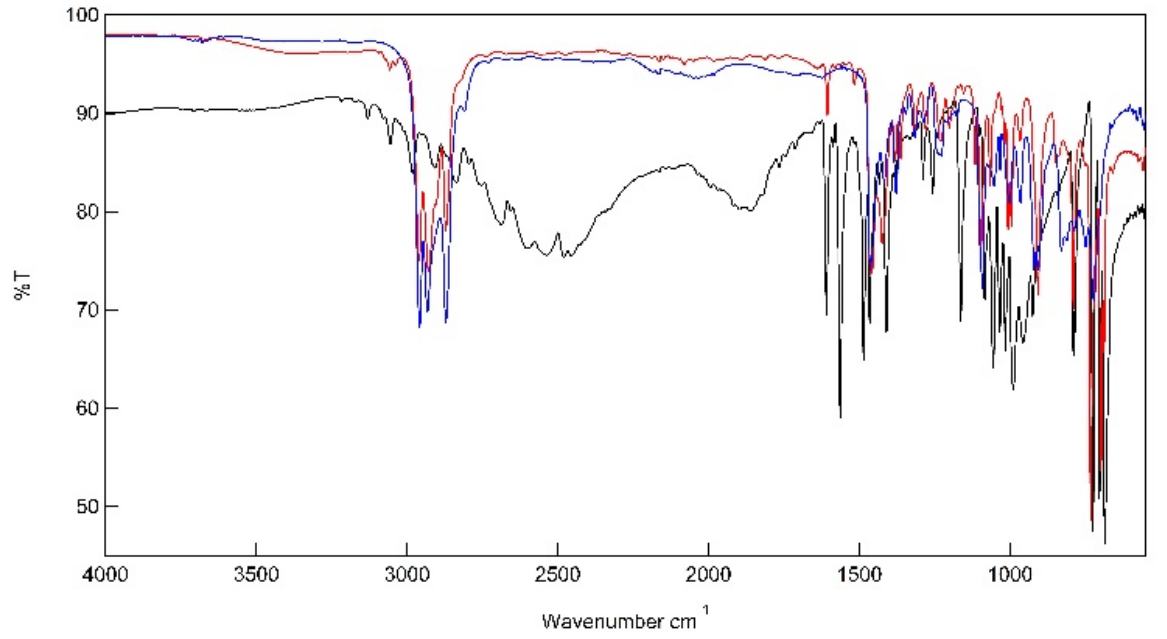

Figure S4. Comparison of the infrared spectra of 5-phenyl-1H-tetrazole (black), $\left[\mathrm{P}_{4444}\right] \mathrm{Cl}$ (blue), and $\left[\mathrm{P}_{4444}\right][\mathrm{Ph}$-tet] $(\mathrm{red})$. 


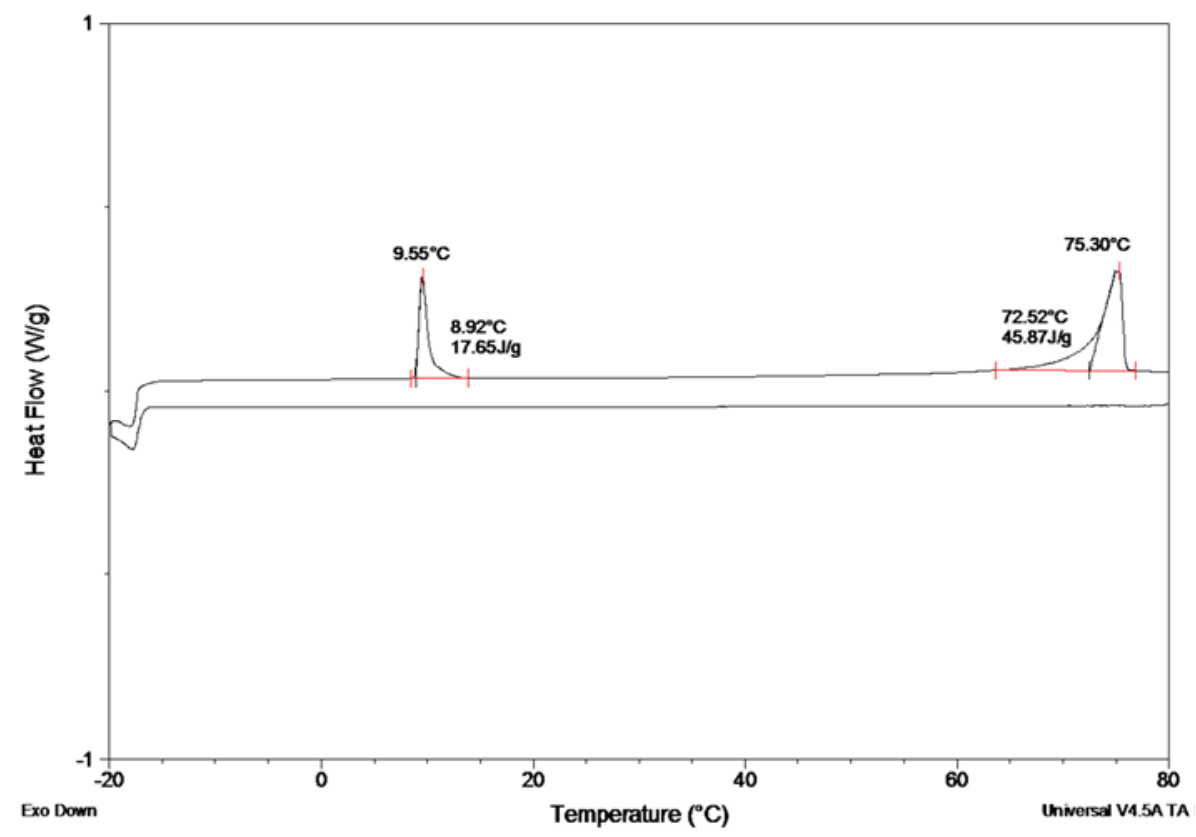

Figure S5. Phase transition behavior of pure $\left[\mathrm{P}_{4444]}\right][\mathrm{Ph}$-tet] shown by DSC. Two exothermic transitions, solid-solid at ca. $10^{\circ} \mathrm{C}$ and melting at $75.3^{\circ} \mathrm{C}$ on heating are evident.

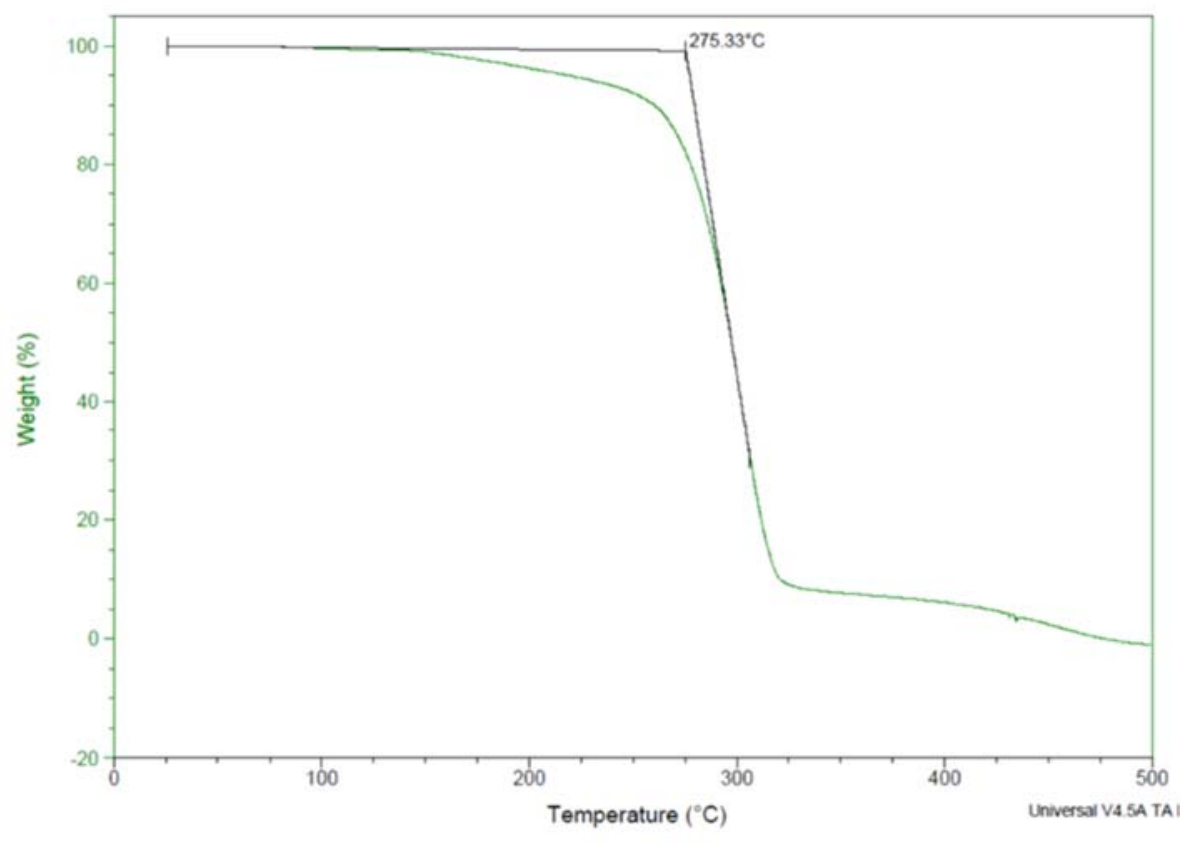

Figure S6. TGA of $\left[\mathrm{P}_{4444}\right][\mathrm{Ph}$-tet] showing single step decomposition.

\section{Analytical}

Microanalyses and electrospray MS were performed by ASEP, Queen's University Belfast.. ${ }^{1} \mathrm{H},{ }^{13} \mathrm{C}$ and ${ }^{31} \mathrm{P}$ NMR spectroscopy in DMSO- $d_{6}$ using a Bruker Avance III $400 \mathrm{MHz}$ spectrometer. FT-IR spectra were performed using a PerkinElmer Spectrum 100 ATR FT-IR spectrometer. The melting point for the pure $\left[\mathrm{P}_{4444}\right][\mathrm{Ph}$-tet] was determined by differential scanning calorimetry (TA DSC Q2000 with a refrigerated cooling system, 5-20 mg samples, $1{ }^{\circ} \mathrm{C} \mathrm{min}-1$ heating and cooling rates 
under dinitrogen, scanning between -100 and $+100^{\circ} \mathrm{C}$ or between -15 and $25{ }^{\circ} \mathrm{C}$ ). The decomposition temperature of $\left[\mathrm{P}_{4444}\right][\mathrm{Ph}$-tet] was measured in the dynamic heating regime using a TA Instruments Q5000 TGA instrument under nitrogen atmosphere. Samples were heated from room temperature to $500{ }^{\circ} \mathrm{C}$ under constant heating rate of $10{ }^{\circ} \mathrm{C} \mathrm{min}-1$. 


\section{Liquid-liquid (LLE) and solid-liquid (SLE) equilibrium measurements}

All liquid-liquid equilibrium (LLE) measurements (cloud-point determinations) on the temperaturecomposition phase diagrams were performed using visual detection in a Pyrex glass cell with magnetic stirring. The samples were prepared in the cells using an analytical balance $(0.1 \mathrm{mg})$. The cells were then immersed in a thermostatic bath. The solutions were heated, usually in two or three consecutive runs with the two last runs being carried out at a rate of around $2{ }^{\circ} \mathrm{C} \mathrm{h}^{-1}$ near the cloud point temperature. Starting from the homogeneous region, the temperature at which the first sign of turbidity appeared upon heating was taken as the temperature of the liquid-liquid phase transition. The mixtures used for the determination of the solid-liquid equilibrium (SLE) were prepared in the same manner as the LLE samples and the detection of phase change was also performed visually in a Pyrex glass cell. The cell was then inserted in a thermostatic water or acetone bath and cooled by adding ice or liquid nitrogen. After solidification, the samples were heated very slowly $\left(2^{\circ} \mathrm{C} \mathrm{h}^{-1}\right)$ with continuous stirring inside the cell during the melting process. The temperature at which the last crystal disappeared was taken as the temperature of the solid-liquid equilibrium (data shown in Table S1).

Both the crystal disappearance temperatures and the cloud point temperatures were measured using an insulated wire miniature type $\mathrm{K}$ Thermocouple model $5 \mathrm{SC}$ coupled with a $\mathrm{HH} 802 \mathrm{U}$ thermocouple thermometer, with an expected measurement uncertainty of $\pm 1.5^{\circ} \mathrm{C}$. The measurement uncertainty resulting from the visual observation of the phase transitions is expected to be greater than the instrumental error.

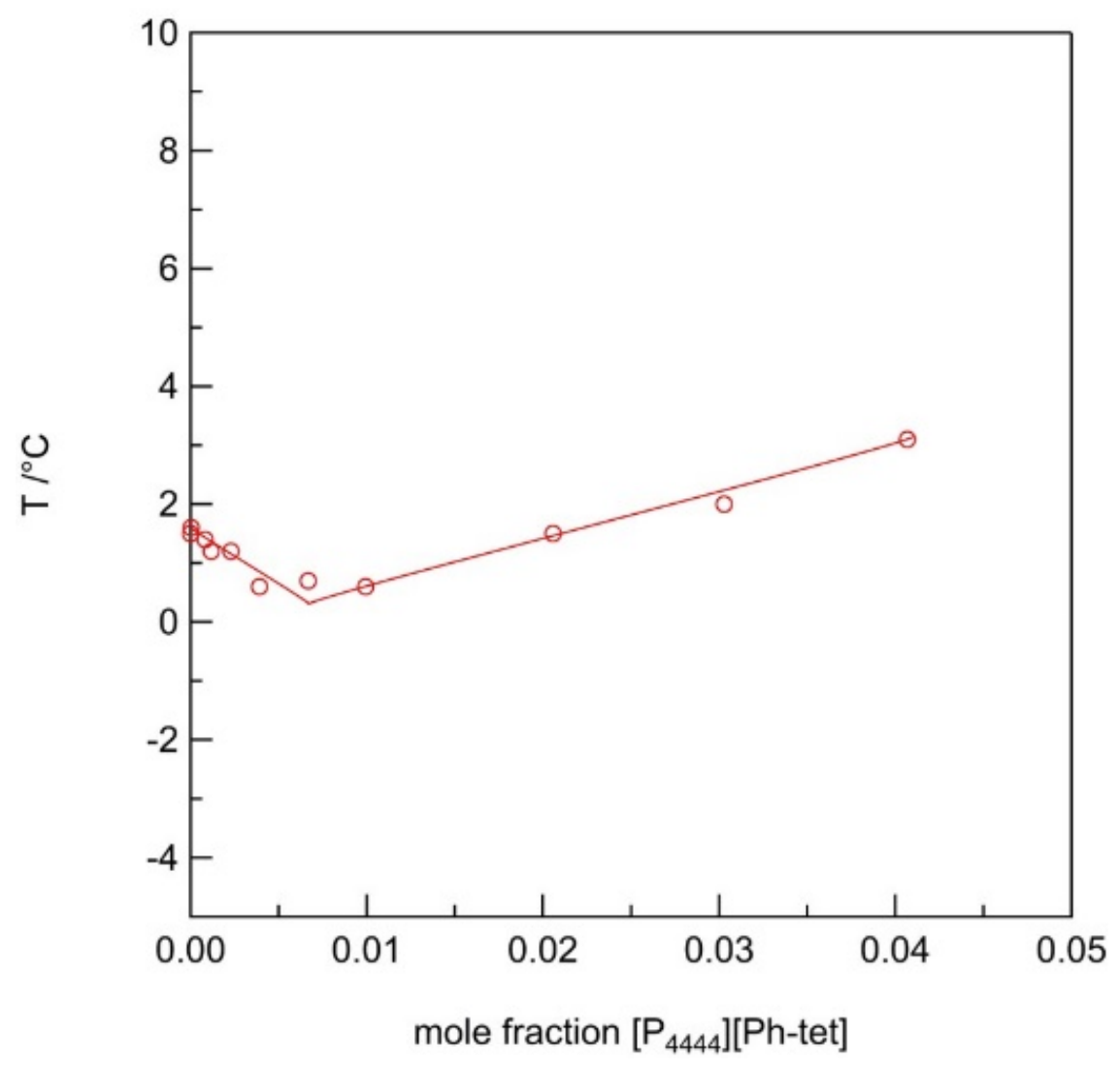


Figure S7. Detailed view of the temperature-composition phase diagram for solutions of [P $\left.\mathrm{P}_{444}\right][\mathrm{Ph}$-tet] $+\mathrm{H}_{2} \mathrm{O}$ as a function of the mole fraction (XIL) of IL for IL mole fractions between 0 and 0.05 showing the solid-liquid equilibria (red squares). We observe the presence of the eutectic point at IL mole fraction $\sim 0.007$. Lines are drawn as visual aids.

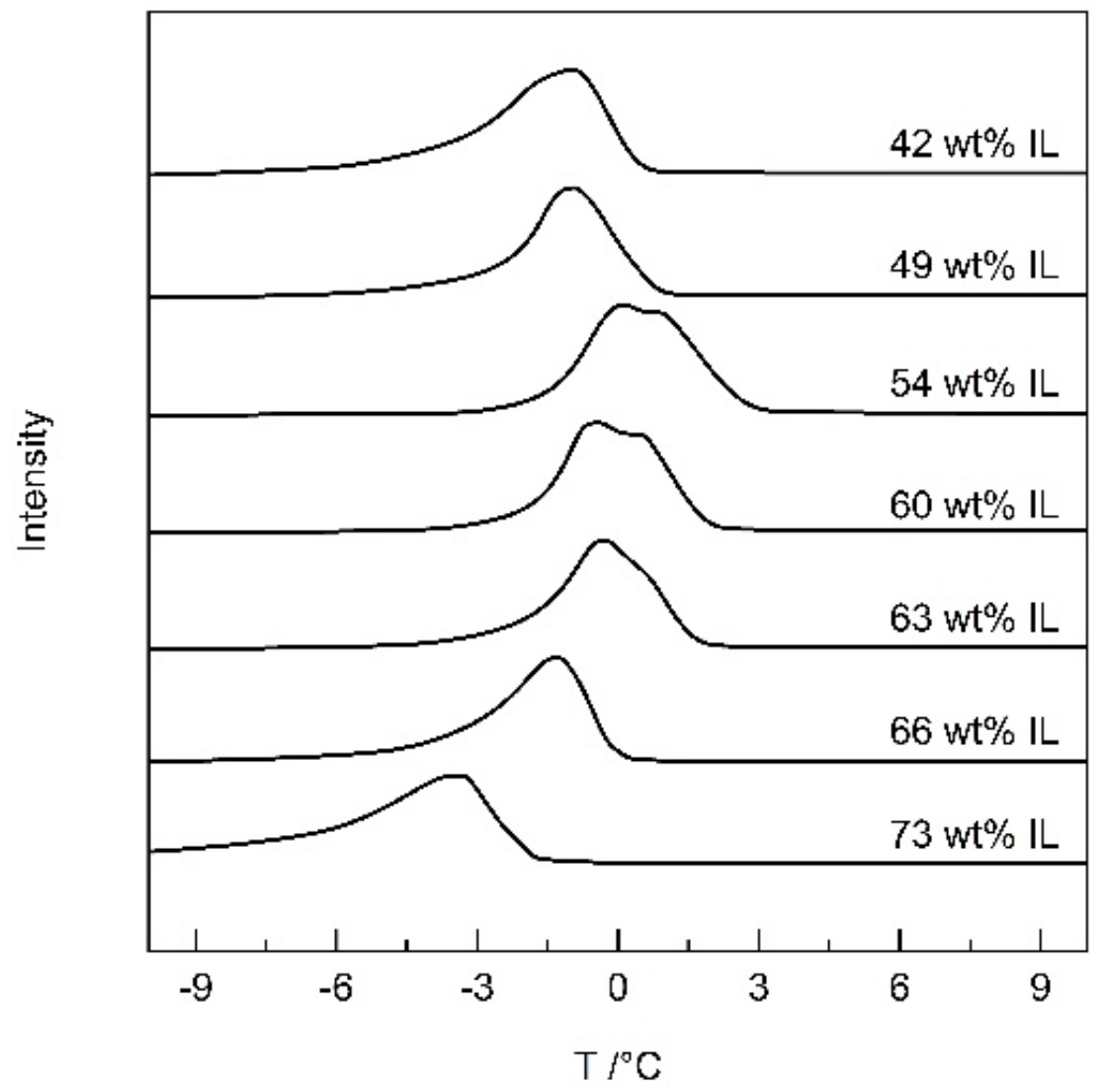

Figure S8. Differential scanning calorimetry analysis of mixtures of $\left[\mathrm{P}_{4444}\right][\mathrm{Ph}$-tet] and water at several compositions $42 \mathrm{wt} \%$ IL (0.032 mole fraction of IL), 49 wt\% IL (0.041 mole fraction of IL), 54 wt\% IL (0.049 mole fraction of IL), 60 wt\% IL (0.062 mole fraction of IL), 63 wt\% IL (0.069 mole fraction of IL), $66 \mathrm{wt} \%$ IL (0.081 mole fraction of IL) and $73 \mathrm{wt} \%$ IL (0.109 mole fraction of IL). We observe the presence of a double peak or a shoulder for mixtures with IL composition between 54 wt\% and 63 wt \%. 
A comparison of the extent of LCST biphase formation in [ $\left.\mathrm{P}_{4444}\right]\left[\mathrm{Ph}\right.$-tet] (in this work) and $\left[\mathrm{P}_{4444}\right][\mathrm{Sal}]$ from Ohno and co-workers is shown in Figure S9, showing the larger composition range encompassed by biphase formation with $\left[\mathrm{P}_{4444}\right]\left[\mathrm{Ph}\right.$-tet] and the higher (ca. $\left.10^{\circ} \mathrm{C}\right)$ onset for LCST.

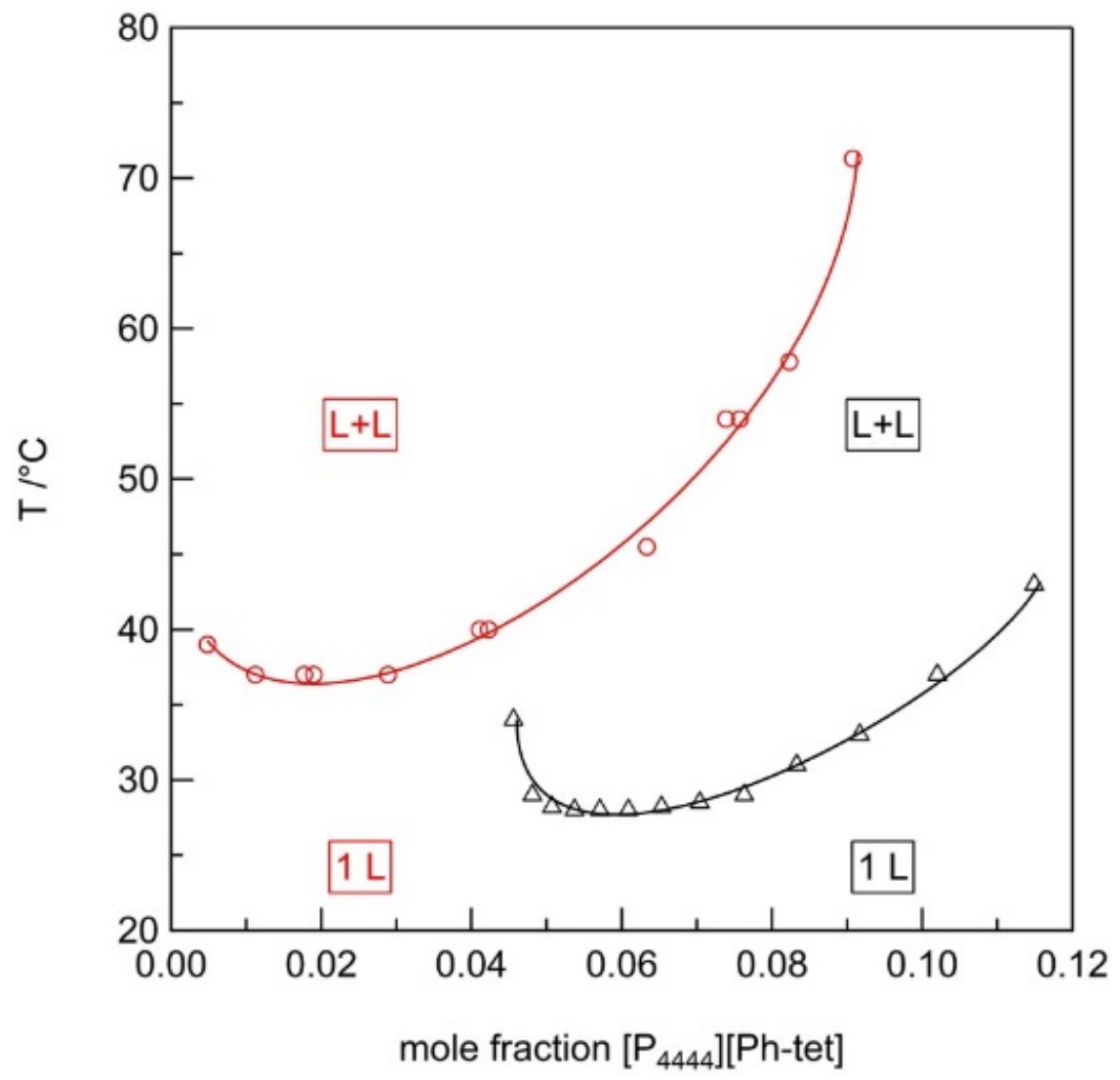

Figure S9. A comparison of the composition range for LCST liquid-liquid biphase formation in water of $\left[\mathrm{P}_{4444}\right]\left[\mathrm{Ph}\right.$-tet] (red circles) and $\left[\mathrm{P}_{4444}\right][\mathrm{Sal}]$ (black triangles) showing the higher temperature required to induce criticality with the tetrazole anion and the wider composition range that displays LCST induced biphase formation.

A comparison of the composition range for LCST liquid-liquid biphase formation in water of $\left[\mathrm{P}_{4444}\right][\mathrm{Ph}$ tet] (red circles) and $\left[\mathrm{P}_{4444}\right][\mathrm{Sal}]$ (black triangles) showing the higher temperature required to induce criticality with the tetrazole anion and the wider composition range that displays LCST induced biphase formation. 
Table S1. Observed SLE and LLE transition temperatures $\left({ }^{\circ} \mathrm{C}\right)$ for $\left[\mathrm{P}_{4444}\right][\mathrm{Ph}$-tet $]+$ water mixtures

\begin{tabular}{|c|c|c|c|}
\hline \multirow{2}{*}{$\begin{array}{c}\text { Mole fraction }\left[\mathrm{P}_{4444}\right][\mathrm{Ph}- \\
\text { tet }] \\
\left(\mathrm{XIL}_{\mathrm{LI}}\right) \text { in water }\end{array}$} & \multirow{2}{*}{$\begin{array}{c}\text { Mass fraction }\left[\mathrm{P}_{4444}\right][\mathrm{Ph}- \\
\text { tet] } \\
\text { (wt\% IL) in water }\end{array}$} & \multicolumn{2}{|c|}{ Transition temperatures $/^{\circ} \mathrm{C}$} \\
\hline & & Solid to liquid (SLE) & Single to biphase (LLE) \\
\hline 0.000000 & 0.000 & 1.5 & \\
\hline 0.000036 & 0.082 & 1.6 & \\
\hline 0.000823 & 1.817 & 1.4 & \\
\hline 0.001178 & 2.581 & 1.2 & \\
\hline 0.002297 & 4.917 & 1.2 & \\
\hline 0.003914 & 8.109 & 0.6 & \\
\hline 0.004843 & 9.81 & & 39.0 \\
\hline 0.006680 & 13.121 & 0.7 & \\
\hline 0.009943 & 18.404 & 0.6 & \\
\hline 0.017736 & 28.75 & & 37.0 \\
\hline 0.019011 & 30.22 & & 37.0 \\
\hline 0.020574 & 32.054 & 1.5 & \\
\hline 0.028892 & 39.94 & & 37.0 \\
\hline 0.030286 & 41.225 & 2.0 & \\
\hline 0.040685 & 48.783 & 3.1 & \\
\hline 0.041067 & 48.90 & & 40.0 \\
\hline 0.042295 & 49.67 & & 40.0 \\
\hline 0.057830 & 57.956 & 13.0 & \\
\hline 0.063337 & 60.18 & 13.5 & 45.5 \\
\hline 0.073872 & 64.06 & & 54.0 \\
\hline 0.075721 & 64.68 & & 54.0 \\
\hline 0.082332 & 66.72 & 16.1 & 57.8 \\
\hline 0.090764 & 69.05 & & 71.3 \\
\hline 0.132746 & 77.38 & 20.2 & \\
\hline 0.151025 & 79.98 & 22.4 & \\
\hline 0.178502 & 82.92 & 23.5 & \\
\hline 0.203470 & 85.16 & 23.3 & \\
\hline 0.215752 & 86.01 & 24.2 & \\
\hline 0.252187 & 88.34 & 23.3 & \\
\hline 0.289332 & 90.10 & 24.7 & \\
\hline 0.328433 & 91.62 & 23.13 & \\
\hline 0.348808 & 92.29 & 21.1 & \\
\hline 0.417458 & 94.12 & 31.85 & \\
\hline 0.482933 & 95.43 & 41.8 & \\
\hline 0.563175 & 96.65 & 46.7 & \\
\hline 0.682136 & 97.96 & 55.6 & \\
\hline 0.776138 & 98.73 & 65 & \\
\hline 0.839940 & 99.15 & 66.4 & \\
\hline 0.907457 & 99.55 & 68.6 & \\
\hline 1.000000 & 100.00 & 74.1 & \\
\hline
\end{tabular}




\section{Crystallography}

Single-crystal X-ray diffraction was determined using fragments of crystal obtained from slow cooling of molten $\left[\mathrm{P}_{4444}\right]\left[\mathrm{Ph}\right.$-tet] ionic liquid and a 0.2 mole fraction solution of $\left[\mathrm{P}_{4444}\right][\mathrm{Ph}$-tet] in water respectively. Data was collected using a SuperNova, Dual, Cu, EosS2 diffractometer. The crystals were kept at $100(2) \mathrm{K}$ during data collection. Using Olex2,[2] the structures were solved with the ShelXT${ }^{[3]}$ structure solution program using Intrinsic Phasing and refined with the ShelXL ${ }^{[3]}$ refinement package using Least Squares minimisation. Non-hydrogen atom positions were fully refined using anisotropic thermal parameters and the hydrogen atoms were initially located at idealized positions and then refined using riding coordinates. Details of the crystal data and structure determination of $\left[\mathrm{P}_{4444}\right][\mathrm{Ph}$-tet] and $\left[\mathrm{P}_{4444}\right][\mathrm{Ph}$-tet $] \cdot 3 \mathrm{H}_{2} \mathrm{O}$ are tabulated in Table S2. Hydrogen Bonds in the crystal structure of $\left[\mathrm{P}_{4444}\right][\mathrm{Ph}$-tet] between methylene hydrogens adjacent to the phosphorus centre of the cation and $\mathrm{N}$ sites on the anion are tabulated in Table S3. Packing diagrams, showing the unit cells for $\left[\mathrm{P}_{4444}\right][\mathrm{Ph}$-tet $]$ and $\left[\mathrm{P}_{4444}\right][\mathrm{Ph}$-tet $] \cdot 3 \mathrm{H}_{2} \mathrm{O}$ are shown in Figures $\mathbf{S} 10$ and $\mathbf{S} 11$ respectively

Table S2. Crystal data and details of the structure determination

\begin{tabular}{|c|c|c|}
\hline Crystal Data & $\begin{array}{l}\text { Tetrabutylphosphonium 5-phenyl- } \\
\text { tetrazolate }\end{array}$ & $\begin{array}{l}\text { Tetrabutylphosphonium } \\
\text { 5-phenyl-tetrazolate trihydrate }\end{array}$ \\
\hline Formula & {$[\mathrm{PC} 16 \mathrm{H} 36][\mathrm{C} 7 \mathrm{H} 5 \mathrm{~N} 4]$} & {$[\mathrm{PC} 16 \mathrm{H} 36][\mathrm{C} 7 \mathrm{H} 5 \mathrm{~N} 4] .3 \mathrm{H} 2 \mathrm{O}$} \\
\hline Formula Weight & 404.57 & 458.61 \\
\hline Crystal System & orthorhombic & Triclinic \\
\hline Space group & Pbca (No. 61) & P-1 (No. 2) \\
\hline$a, b, c[\AA]$ & 15.4906(2), $16.6321(2), 18.9638(2)$ & $8.0323(3), 13.1416(3), 14.6038(5)$ \\
\hline$\alpha, \beta, y /{ }^{\circ}$ & $90,90,90$ & 67.317(3), 87.595(3), 72.787(3) \\
\hline V IÅ3 & 4885.86(10) & $1354.04(9)$ \\
\hline $\mathbf{z}$ & 8 & 2 \\
\hline Dcalc /g cm-3] & 1.100 & 1.125 \\
\hline$F(000)$ & 1776 & 504 \\
\hline $\mathrm{T} / \mathrm{K}$ & 100 & 100 \\
\hline$\theta \min , \max /^{\circ}$ & $4.5,68.8$ & $3.8,72.5$ \\
\hline Reflections measured & 22922 & 25418 \\
\hline Independent reflections, Rint & $4012,0.027$ & $5287,0.024$ \\
\hline Observed Data [I > $\sigma(\mathrm{I})]$ & 3740 & 5103 \\
\hline Nref, Npar & 4012, 257 & 5287, 293 \\
\hline$R, \omega R 2, S$ & $0.0435,0.1180,1.04[a]$ & $0.0323,0.0852,1.02[\mathrm{~b}]$ \\
\hline
\end{tabular}

[a] $\omega=1 /\left[\sigma^{2}\left(F_{o}^{2}\right)+(0.0740 P)^{2}+1.7290 P\right]$ where $P=\left(F_{o}^{2}+2 F_{c}^{2}\right) / 3$.

[b] $\omega=1 /\left[\sigma^{2}\left(F_{o}^{2}\right)+(0.0419 P)^{2}+0.5710 P\right]$ where $P=\left(F_{o}^{2}+2 F_{c}^{2}\right) / 3$ 
Table S3. Hydrogen Bonds in the crystal structure of $\left[\mathrm{P}_{4444}\right][\mathrm{Ph}$-tet] between methylene hydrogens adjacent to the phosphorus centre of the cation and $\mathrm{N}$-sites on the anion.

\begin{tabular}{|c|c|c|c|c|}
\hline Hydrogen bond & Donor-H IA & H-acceptor $/ \AA$ & Donor $\cdots$ Acceptor $/ \mathbb{A}$ & D-H-A angle $/^{\circ}$ \\
\hline $\mathrm{C} 5-\mathrm{H} 10 \ldots \mathrm{N} 1$ & 0.9700 & 2.5300 & $3.487(2)$ & 168.00 \\
\hline $\mathrm{C} 5-\mathrm{H} 11 \ldots \mathrm{N} 4$ & 0.9700 & 2.4300 & $3.384(2)$ & 168.00 \\
\hline $\mathrm{C} 9-\mathrm{H} 19 \ldots \mathrm{N} 2$ & 0.9700 & 2.5600 & $3.479(2)$ & 158.00 \\
\hline C9-H19...N3 & 0.9700 & 2.6000 & $3.377(2)$ & 138.00 \\
\hline
\end{tabular}

Table S4. Hydrogen Bonds in the crystal structure of $\left[\mathrm{P}_{4444}\right][\mathrm{Ph}-\mathrm{tet}] \cdot 3 \mathrm{H}_{2} \mathrm{O}$. Principle hydrogen-bonds are found between single water molecule bridges between tetrazolate anions and bridging four-water rectangles and tetrazolate anions.

\begin{tabular}{|c|c|c|c|c|}
\hline Hydrogen bond & $\begin{array}{c}\text { Donor-H } \\
\text { IA }\end{array}$ & $\underset{I A}{\mathrm{H} \text {-acceptor }}$ & $\begin{array}{c}\text { Donor } \cdots \text { Acceptor } \\
I \AA\end{array}$ & D-H-A angle $I^{\circ}$ \\
\hline O1-H41...N3 & 0.8500 & 2.0700 & $2.9074(15)$ & 170.00 \\
\hline $\mathrm{O} 1-\mathrm{H} 42 \ldots \mathrm{N} 2$ & 0.8500 & 2.0200 & $2.8528(15)$ & 167.00 \\
\hline $\mathrm{O} 2-\mathrm{H} 43 \ldots \mathrm{N} 4$ & 0.8500 & 2.0300 & $2.8507(16)$ & 162.00 \\
\hline O2-H44...O3 & 0.8500 & 2.0100 & $2.8584(15)$ & 172.00 \\
\hline O3-H45...O2 & 0.8500 & 2.0700 & $2.8876(15)$ & 162.00 \\
\hline O3-H46...N1 & 0.8500 & 2.1600 & $2.9303(15)$ & 151.00 \\
\hline $\mathrm{C} 6-\mathrm{H} 12 \ldots \mathrm{O} 1$ & 0.9700 & 2.5400 & $3.1322(16)$ & 119.00 \\
\hline C13-H6AA...O1 & 0.9700 & 2.4400 & $3.3079(16)$ & 149.00 \\
\hline C9-H19...О3 & 0.9700 & 2.5200 & $3.3965(16)$ & 151.00 \\
\hline $\mathrm{C} 11-\mathrm{H} 23 \ldots \mathrm{O} 2$ & 0.9700 & 2.5500 & $3.4707(16)$ & 158.00 \\
\hline $\mathrm{C} 23-\mathrm{H} 40 \ldots \mathrm{O} 1$ & 0.9300 & 2.5400 & $3.4548(16)$ & 166.00 \\
\hline $\mathrm{C} 23-\mathrm{H} 40 \ldots \mathrm{N} 2$ & 0.9300 & 2.6300 & $2.9288(18)$ & 100.00 \\
\hline
\end{tabular}




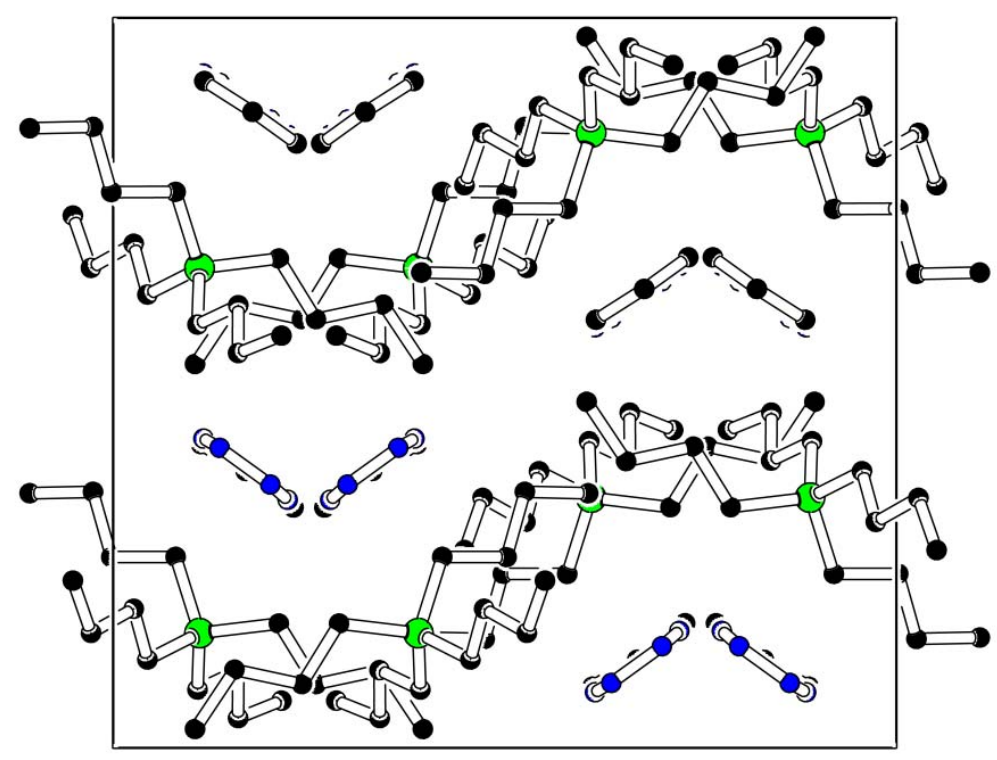

Figure S10. Packing diagram for $\left[\mathrm{P}_{4444}\right][\mathrm{Ph}$-tet] showing association of cation alkyl-chains forming an undulating layer structure in the crystal and hydrogen-bonding from the cation $\mathrm{PCH}_{2}$ hydrogens to the [Ph-tet]' anions. 


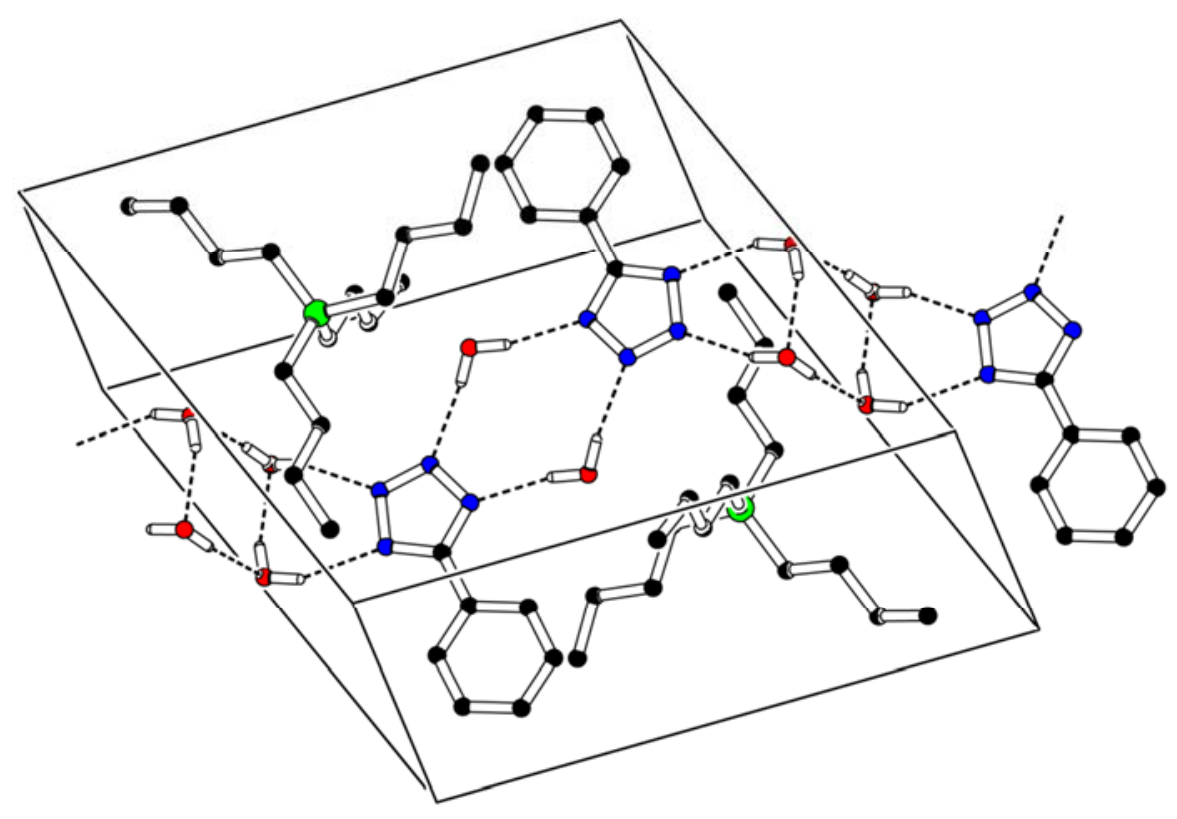

Figure S11. Packing diagrams for $\left[\mathrm{P}_{4444}\right]\left[\mathrm{Ph}\right.$-tet] $\cdot 3 \mathrm{H}_{2} \mathrm{O}$ showing the catenar formation of anion+water hydrogen-bonded ribbons through the crystal. 


\section{References}

[1] S. C. S. Bugalho, E. M. S. Maçôas, M. L. S. Cristiano, R. Fausto, Phys. Chem. Chem. Phys. 2001, 3, 3541-3547.

[2] O. V. Dolomanov, L. J. Bourhis, R. J. Gildea, J. A. K. Howard, H. Puschmann, J. Appl. Cryst. 2009, 42, 339-341.

[3] G. M. Sheldrick, Acta Cryst. A 2015, 71, 3-8. 